\title{
The Sovereign-Debt Listing Puzzle
}

\author{
Elisabeth de Fontenay, Josefin Meyer \& Mitu Gulati* \\ Draft Version: November 1, 2016
}

\begin{abstract}
Why do almost all sovereign nations list their international bonds on stock exchanges? We provide the first comprehensive report on sovereigns' listing patterns for the entire postWorld War II period, and examine several hypotheses for what drives sovereigns to list and where. In particular, we test whether stock exchanges perform a certification and monitoring role for sovereign debt, and find little support for this "bonding hypothesis" today: we find no consistent association between the exchange chosen for a sovereign-bond issue and its yield. In contrast, we argue that sovereign-bond listings are primarily a form of regulatory arbitrage. There is a widespread belief in the sovereign-debt market that certain investors can invest in foreign securities only if they are listed on an exchange. Sovereigns are thus incentivized to list their bonds, but to seek out the least restrictive exchange that qualifies, triggering a race to the bottom among exchanges. We conclude that sovereign-bond listings no longer add value for investors.
\end{abstract}

\footnotetext{
* de Fontenay (defontenay@law.duke.edu) and Gulati (gulati@law.duke.edu) are at Duke Law School. Meyer (josefin.meyer@econ.lmu.de) is at the University of Munich Department of Economics and has received funding from the People Programme (Marie Curie Actions) of the European Union's Seventh Framework Programme FP7/2007-2013/ under REA grant agreement n 608129.
} 


\section{Introduction}

Apart from a handful of the highest-quality issuers, sovereign nations all choose to list their international bonds on one of the prominent international stock exchanges. Yet little is known about where they list and why they do so. Sovereign listings present a puzzle, because international sovereign bonds are very rarely traded on their listed exchange, and stock exchanges would seem to have little ability to enforce investors' interests against sovereign nations. To investigate this puzzle, we constructed what we believe is the largest dataset on sovereign-bond listings, covering the entire post-World War II period. We hypothesize that sovereign listings are primarily a form of regulatory arbitrage: sovereigns list solely to satisfy possible investor requirements for listed securities, and thus gravitate toward the international exchanges that offer the cheapest, fastest, and least burdensome listing process.

This finding is in direct contrast to the dominant explanation in the financial and legal literatures for why issuers list securities on a foreign stock exchange. The bonding hypothesis points to the purported certification and monitoring roles played by major stock exchanges for foreign issuers (Coffee, 1999). ${ }^{1}$ By listing on a major foreign stock exchange, the theory goes, an issuer bonds itself to honor its implicit and explicit commitments to security holders. The notion is that complying with the listing standards set by the exchange sends a credible signal to the market of the issuing firm's quality and serves to control moral hazard. As a historical matter, exchange listing appears to have been a crucial signal of credibility for sovereigns as early as the 1800s, when the London Stock Exchange attracted the bulk of sovereign debt issuances and maintained a reputation for rigorously policing issuers (Wright, 2012; Flandreau, 2013). Institutions through which issuers can signal credibility have long been considered especially important in the sovereign context, because of the difficulty investors face in using more conventional methods of legal enforcement (Flandreau and Flores, 2009; Panizza et al., 2009). The theory that exchanges might play this credibility enhancing role has not been tested in the modern era of sovereign debt, however.

If the bonding hypothesis holds, listing on one of the major global exchanges should lower the yield at issuance on a particular sovereign's foreign bonds, all else equal. In practice, however, there are considerable obstacles to testing for this yield effect directly. Comparing the

\footnotetext{
${ }^{1}$ Indeed, the fact that the most credible and established sovereigns do not list their bonds on any exchange, while all others choose to do so, plausibly suggests that listing may provide a credibility signal to investors.
} 
bond yields of those sovereigns that list and those that do not would be inconclusive, because the very small subset of elite sovereigns that forgo listing - including the United States, Japan, the United Kingdom, France, the Netherlands, and Australia-differs markedly from all other sovereigns in credit risk and other characteristics that primarily determine bond yields. Comparing the foreign-listed bonds and the domestically-listed or unlisted bonds of the very same sovereigns also proves problematic. In general, there are key contractual and other differences between a sovereign's foreign bonds, which are expected to be traded internationally and listed on a foreign exchange, and its local bonds, which are primarily held by domestic investors and either unlisted or listed on the issuer's domestic exchange (Bradley et al., 2016; Chamon et al., 2014), making it difficult to isolate the particular effect of listing on such bonds' yields. Further, the bonding benefits (if any) of a sovereign's listed bonds should also inure at least in part to the holders of its unlisted bonds.

Rather than examining the choice to list or not, therefore, our empirical tests focus instead on a sovereign's choice among the various global exchanges, once the decision to list has been made. Specifically, we test whether there are differences in bond yields across the different exchanges themselves, controlling for various issuer and bond-level characteristics. If the bonding hypothesis holds, we would expect some degree of sorting of sovereign issuers across the exchanges by quality and credibility, due to differences in the exchanges' listing standards, their reputation for monitoring issuers, and any laws in the jurisdiction applicable to sovereign bonds. ${ }^{2}$ Such differences in the strength of the signal provided by the issuer should thus give rise to differences in yield, all else equal, which would not be eliminated by arbitrage. ${ }^{3}$ The exchange requiring the greatest degree of bonding should be associated with the lowest yields, and so on, similarly to the predictions for cross-listing firms (Coffee, 1999) and for domestic firms choosing from among local exchanges of varying stringency (Campbell and Tabner, 2014). In fact,

\footnotetext{
${ }^{2}$ In some jurisdictions such as the United States, by listing on an exchange the issuer becomes bound not only by the exchange's rules and listing standards, but also by the country's securities laws. Thus, the credibility afforded by the exchange listing could stem in part (or primarily) from that jurisdiction's background law. Even in such jurisdictions, however, sovereigns tend to be largely exempt from securities regulations such as disclosure requirements.

${ }^{3}$ Even if all issuers could potentially satisfy the requirements of the strictest exchange, for example, the lowest-quality sovereigns (those most susceptible to moral hazard, for example) should find it the costliest to do so, leading to the self-sorting of issuers by exchange (Doukas and Hoque, 2016). Our empirical test therefore assumes (1) that investors cannot perfectly observe a sovereign issuer's quality and (2) that the costs and benefits of listing vary in some way with the issuer's unobservable quality.
} 
however, we find little evidence to support the bonding hypothesis in today's sovereign-bond market: none of the major jurisdictions is consistently associated with a significant yield differential.

We confirm this result with a review of the top exchanges' listing requirements and responses from forty-four elite lawyers involved in international sovereign-debt work. We find that, contrary to the bonding hypothesis, the top listing jurisdictions for sovereign bonds compete primarily on the ease and speed with which they grant listing approvals. For nearly thirty years, the Luxembourg Stock Exchange has been the overwhelming favorite among the global exchanges for international sovereign-bond offerings. Most recently, we find that the Irish Stock Exchange has been rapidly gaining market share. Yet the popularity of Luxembourg and now Dublin fits poorly with a bonding story. Both jurisdictions are characterized by the near absence of substantive listing standards and enforcement for sovereigns. While Ireland first gained market share as the jurisdiction of choice for first-time, low-rated sovereigns, it now attracts a wide range of issuers, by explicitly marketing itself as the fastest jurisdiction for listings. In practice, the only hurdle to obtaining a sovereign-bond listing in any of the top jurisdictions is the payment of a modest fee. Thus, the lack of observable yield differentials between the various exchanges is likely best explained by the fact that none of them actually performs a screening or monitoring function.

Yet if listing does not increase a sovereign's credibility with investors, we are left with the original puzzle of why sovereigns choose to list at all. We hypothesize that sovereign listings are primarily a form of regulatory arbitrage, driven by a hodge-podge of investment restrictions across the globe that may cause certain investors to favor listed securities, regardless of the exchange's jurisdiction. Such restrictions-or the mere belief in their existence-prompt sovereigns to list on the fastest, cheapest, and most permissive exchange that qualifies, which in turn induces a race to the bottom among the exchanges.

The policy implications are significant: if this explanation is correct, the practice of listing sovereign bonds abroad is merely a costly response to investment restrictions that, in the absence of any bonding effect from listings, no longer serve an obvious purpose. While the major securities exchanges have historically served a crucial private ordering function, this role has largely dissipated in today's sovereign-debt market. 
The remainder of the article proceeds as follows. Part 2 surveys the relevant literatures on the motivations for exchange listings. Part 3 details the construction of our data set and provides key descriptive facts about sovereigns' listing patterns over time. Part 4 reports test results. Part 5 discusses alternative explanations for the current listing patterns. Part 6 concludes.

\section{Prior Literature}

Recent research in law and finance focuses on the price impact of specific contractual terms and other features of sovereign bonds, such as collective action clauses (e.g., Becker et al., 2003; Gugiatti and Richard, 2003; Eichengreen and Mody, 2000 and 2004; Bradley and Gulati, 2013) and governing law (e.g., Choi et al., 2011; Clare and Schmidlin, 2014; Chamon et al., 2014). We examine the price impact of a sovereign's choice of exchange on which to list its international (or foreign) bonds - that is, sovereign bonds intended for foreign investors. Sovereign issuers may choose from a wide range of international or local exchanges, which can vary in terms of listings standards, monitoring and enforcement, applicable law, trade volume, fees, and ease and speed of the approval process. Whether to list and where are among the key decisions that sovereigns must make at the outset when issuing bonds.

Although the practice of listing international sovereign bonds is nearly ubiquitous, to our knowledge no prior literature addresses for the modern era why sovereign issuers choose to list their bonds on an exchange, where they choose to list, or how those choices have evolved over time. While there is a long literature on the historic roles played by stock exchanges (e.g., Mahoney, 1997; Macey and O'Hara, 2002), the specific context at issue involves issuers listing their securities on an exchange in a foreign jurisdiction. The most analogous literature concerns the practice of "cross-listing," in which non-U.S. firms whose stock is listed on a domestic exchange choose to obtain a secondary listing on one of the major U.S. stock exchanges such as the NYSE or Nasdaq (Stulz, 1999; Coffee, 1999 and 2002). The cross-listing inquiry has spawned a long empirical and theoretical literature in corporate finance, yielding two major hypotheses to explain the practice.

First, under the bonding hypothesis, cross-listing amounts to a firm's pledge of "good" behavior toward investors (Stulz, 1999; Coffee, 1999; Reese and Weisbach, 2002; Doidge et al., 
2004). ${ }^{4}$ By listing on an exchange, the firm commits to abiding by the exchange's rules and listing standards, and in many cases the securities laws of the relevant jurisdiction. Together, these may require substantial disclosure by the firm (including in particular audited financial statements and discussion of material conflicts of interest), as well as compliance with substantive corporate governance requirements. Listing on a reputable foreign stock exchange can thus send a credible signal to the market of the issuing firm's quality and serve to control moral hazard.

Second, the market segmentation hypothesis (or liquidity hypothesis, as we will refer to it), posits that investment markets are (or were) segmented worldwide by regulatory restrictions, transaction costs, and information problems, all of which burden cross-border investing (e.g., Stapleton and Subrahmanyam, 1977; Errunza and Losq, 1985). By secondarily listing its stock on a U.S. exchange, for example, a foreign firm might better access the liquidity provided by the massive U.S. investor base.

Empirical studies of cross-listing have found support for both hypotheses (e.g., Foerster and Karolyi, 1999; Reese and Weisbach, 2002; Doidge 2004, Doidge et al. 2009), though the most recent studies (described in Karolyi, 2012; see also Doukas and Wang, 2014) suggest that they may be losing some explanatory force in a world of declining barriers to international investing and more integrated capital markets. As with cross-listing firms, sovereigns might select particular foreign stock exchanges on which to list their bonds in order (1) to provide an ongoing signal of credibility to investors (the bonding hypothesis) or (2) to better access foreign investors (the liquidity hypothesis). In the sovereign-debt context, only the bonding hypothesis has figured prominently in the literature, and only with respect to pre-War periods. In the $1800 \mathrm{~s}$, for example, sovereign issuers flocked to the London Stock Exchange, which developed a reputation for promptly delisting any sovereign that defaulted on its bonds (Wright, 2012; Flandreau, 2013). This would have effectively cut off the affected sovereign's access to international investors, thus providing strong ex ante incentives for issuers to avoid defaulting.

\footnotetext{
${ }^{4}$ Specifically, the cross-listing literature focuses on the role played by a foreign (in this case, U.S.) exchange listing in reducing management and controlling shareholder agency costs. In this view, firms in jurisdictions with weak disclosure requirements and protections for minority shareholders can plausibly lower their cost of capital by listing secondarily in stricter jurisdictions, with the secondary listing(s) serving as a bonding mechanism for the firm.
} 
We test the bonding hypothesis in Part 4 using our sample of international sovereign-bond issues; Part 5 discusses the liquidity hypothesis.

In the lone prior empirical study of sovereign bonds that takes into account listings, Bradley et al. (2016) examine the effect on yield at issuance of a sovereign's decision to issue bonds under "local" versus "foreign" parameters, including governing law, currency, and listing jurisdiction. The authors do not find a consistent effect on yield from listing on a foreign exchange versus a local one. Under specifications that appear to show that foreign listings are significantly associated with a reduction in yield, the effect appears to be driven by the more salient "foreign" parameters of currency and governing law, with which foreign listings are highly correlated. By combining all of the different foreign exchanges into a single category, Bradley et al. (2016) do not inquire whether there are differences among the exchanges that might entail differences in the degree to which they can perform a bonding role, if at all.

\section{Description of Data}

\subsection{Construction of dataset}

Our data consist of 5,896 bond issuances by national sovereigns from 1945 through 2015, representing what we believe to be the most comprehensive dataset of sovereign bonds to date for the post-World War II period. Issuances prior to 1980 were coded entirely by hand from the offering circulars or prospectuses for available sovereign debt offerings. ${ }^{5}$ The documents were obtained directly from the major exchanges themselves (including the London Stock Exchange, the New York Stock Exchange, the Tokyo Stock Exchange, and the Luxembourg Stock Exchange), from the archives of major banks that have underwritten sovereign debt, museums, university and other private collections, and records kept by central banks (for Switzerland and Germany). Gaps remain in the data, however, as we were unable to obtain records from certain exchanges (including, notably, the Frankfurt Stock Exchange). Nonetheless, a substantial proportion of the bonds for this period have never been identified in prior literature (e.g., Bradley et al., 2016).

\footnotetext{
${ }^{5}$ We rely on offering circulars and prospectuses for the bond terms, because in most cases we do not have access to the underlying bond contracts (the underwriting agreements or bond indentures). We believe that such reliance is justified, given that market participants routinely do the same and that issuers and underwriters are potentially liable for inaccurate disclosures.
} 
For issuances from approximately 1980 onwards, our dataset was constructed from both the Dealogic DCM Analytics database (which codes key characteristics of sovereign debt issuances, including the exchange listing) and from hand-coded bond prospectuses and offering circulars taken from two electronic databases, Thomson One Banker and Perfect Information. We report only on sovereign bonds listed on foreign securities exchanges, rather than on the issuer's domestic exchange(s). (Foreign-listed bonds are especially important in the context of the bonding hypothesis, because foreign exchanges are presumably harder for sovereigns to capture than a local one would be.)

Our set of issuers consists solely of national sovereigns, including central banks issuing on behalf of their national sovereigns, and we exclude instruments with a maturity of less than two years. For each issuance, we code basic terms of the bond contract and characteristics of the issuance, including the issue date, maturity date, yield at issuance, coupon rate, currency, principal amount, exchange listing, and governing law. Where the yield at issuance is unavailable, we assume that the bond was issued at par and thus use the coupon rate as a proxy. We further code the law firms representing the issuer and the underwriter, respectively, the lead underwriter, and the number of banks in the syndicate. Finally, we supplement our data with the Standard \& Poor's (S\&P) long-term, foreign-currency debt ratings for each sovereign issuer at the time of the issuance.

Overall, we compiled data on 5,523 bonds, using hand-collected information for 1,764 bonds and relying at least in part on electronic databases for another 3,759 bonds. To minimize errors, we cross-checked multiple sources where available. Our final sample was constructed as follows. First, we dropped all bonds with no listing information, reducing our sample to 4,451. Second, we treated issuances that were simultaneously listed on multiple exchanges as separate issuances for each listing jurisdiction, increasing our sample to 4,824 bonds. Third, we dropped all bonds listed on the issuer's domestic exchange, reducing our sample to 4,241 bonds. Finally, we dropped all bonds issued in connection with a sovereign-debt restructuring, because such bonds were unlikely to have been issued at market yields. To summarize, our final dataset comprises 4,231 sovereign bonds issued by 121 countries and listed on 24 foreign stock exchanges over a period of 70 years - from 1945 to 2015. Tables 1-4 provide summary statistics. 


\subsection{Growth of the overall market}

Figure 1 shows the number of sovereign-bond issuances listed on foreign securities exchanges over time. In the aftermath of World War II, activity in the sovereign bond market remained weak for over thirty years. From the 1980s onwards, however, foreign listings surged, prompted by the development of the Eurobond market and by the Brady Bonds issued to restructure the syndicated bank loans of various Latin American sovereigns. ${ }^{6}$

Figure 1 further reveals that the practice of listing foreign bonds simultaneously on multiple exchanges became widely popular in the 1990s, but fell out of favor in the 2000s.

\section{Figure 1 Foreign sovereign bond listings, 1945-2015}

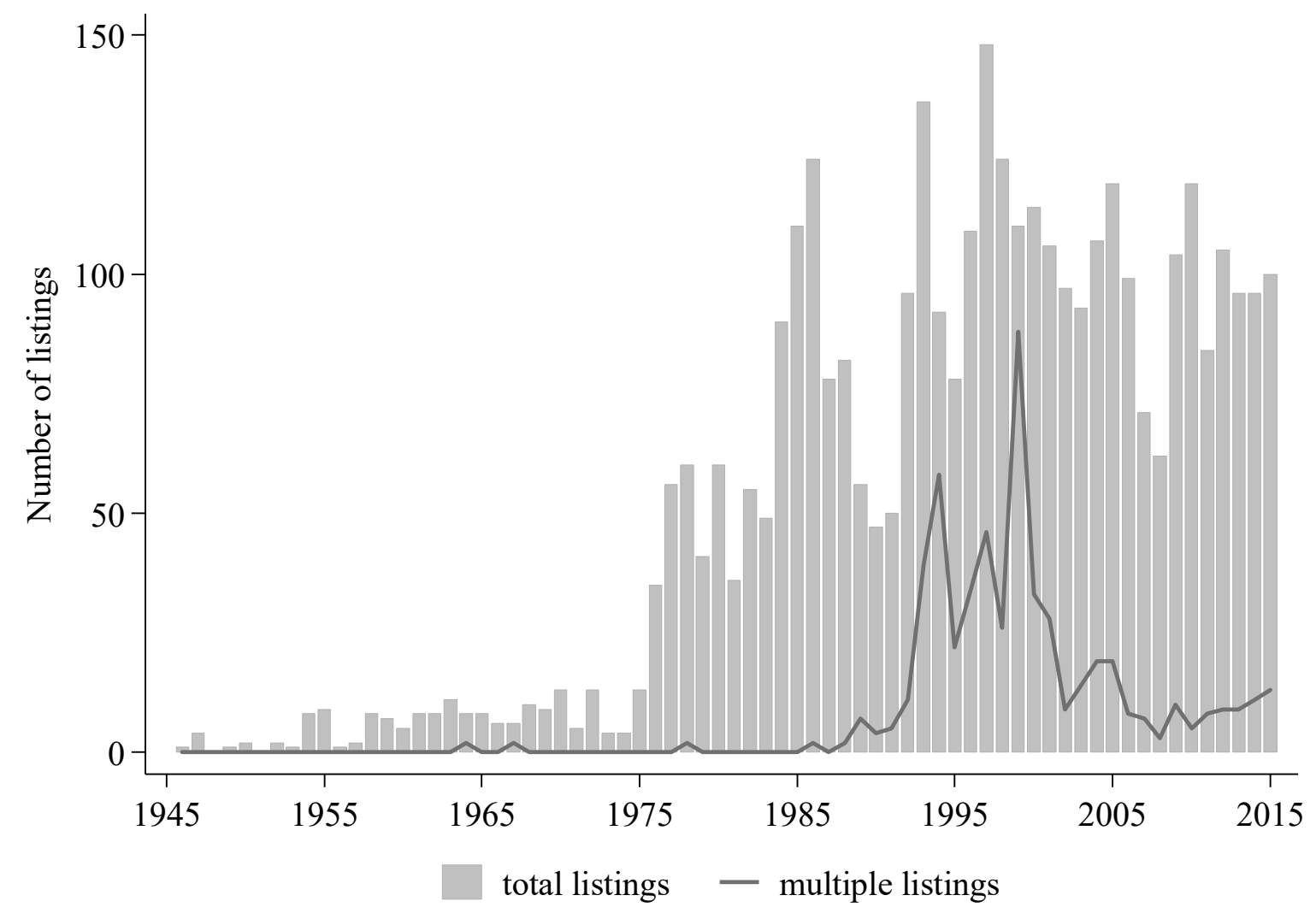

\footnotetext{
${ }^{6}$ Prior to that time, sovereign debt primarily took the form of syndicated bank loans.
} 


\subsection{Foreign listings occur in waves}

Figure 2 displays the share of aggregate bond issuances in each year of each of the top ten international exchanges for sovereign debt listings (Luxembourg, Germany, London, Switzerland, New York, Tokyo, Paris, Singapore, Dublin and Hong Kong), for the entire postWorld War II period. ${ }^{7}$ It reveals several major historical trends in sovereign debt listing patterns. First, and most dramatically, the dominant exchange for sovereign debt listings has shifted over time-from London, through World War I (as reported in Michie, 1999; Wright, 2012; Flandreau, 2013), to New York, to Luxembourg. Though it receives little mention in the literature, we find that New York held the majority of the market share for foreign sovereign debt listings for roughly the first thirty-five years after World War II (until approximately 1980), at which point Luxembourg steadily began to capture market share. By the early 1990s, Luxembourg was the dominant exchange and virtually no sovereigns continued to list in New York. Of the 331 sovereign bonds issued between 1945 and 1979, for example, 41\% were listed on the New York Stock Exchange. In comparison, of the 3,816 sovereign bonds issued between 1980 and 2015, only $36(0.9 \%)$ were listed on the NYSE, while 2,172 (52\%) were listed on the Luxembourg Stock Exchange. As of the writing of this paper, no sovereign nation has listed its bonds on the NYSE since Lebanon in 2005 and, prior to that, Uruguay in 1999.

Also noteworthy in Figure 2 is that the shift to Luxembourg was not merely a shift away from New York, but away from the other leading listing jurisdictions at the time, such as Switzerland and Germany. In the 1980s, there was a distinct change in sovereigns' listings preferences, which manifested in a widespread shift toward Luxembourg. Subsequently, and all the way up to the present day, Luxembourg has retained its leader status and has consistently held more listings than any of the other top five exchanges and Ireland (combined).

\footnotetext{
${ }^{7}$ In the case of both Germany and Switzerland, the listing figures reported here represent aggregate listings across their respective regional stock exchanges.
} 
Figure 2 Top exchanges: Share of listings by year (in \%), 1945-2015

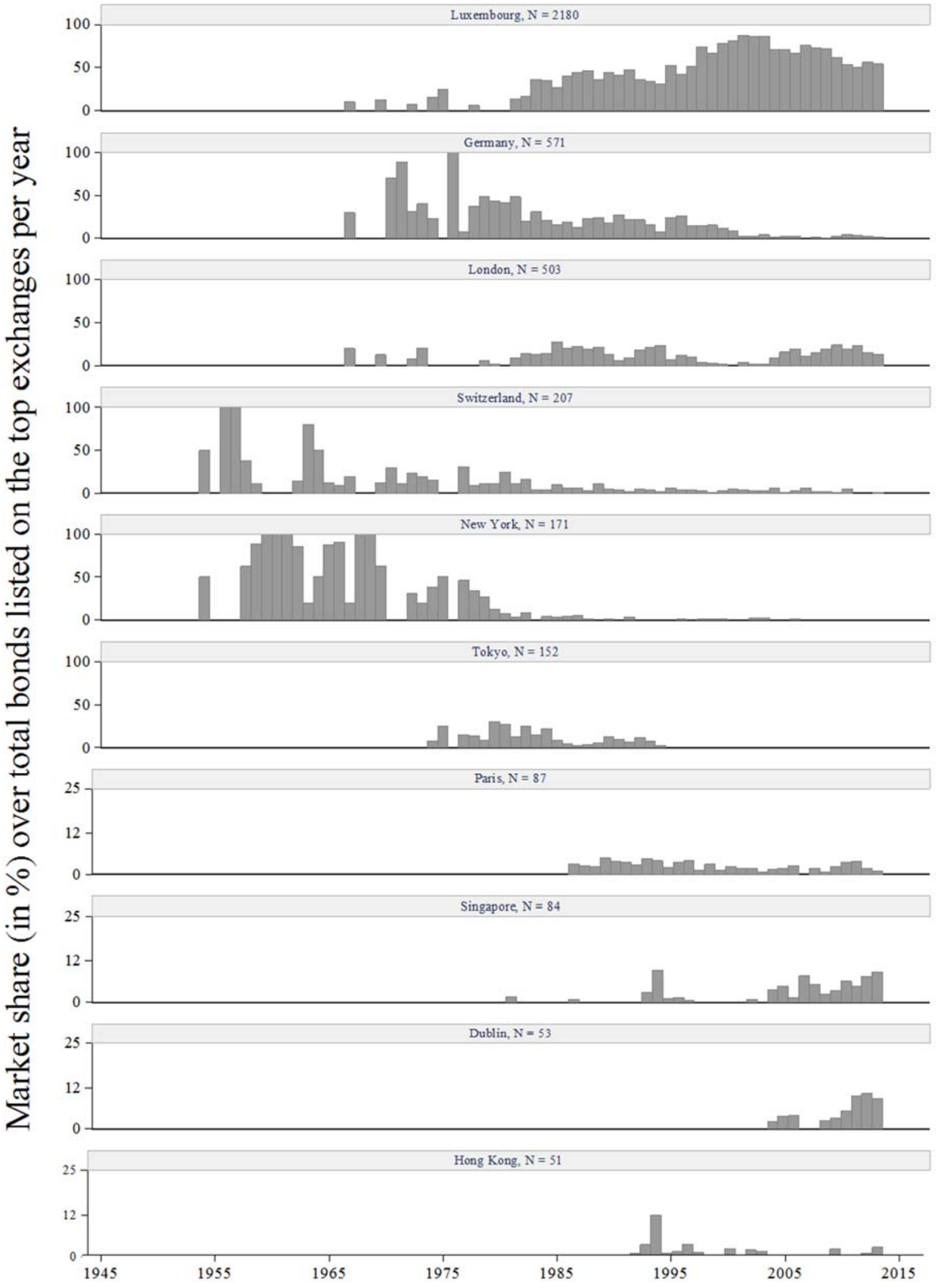


Similarly, we find that Switzerland was one of the first jurisdictions to begin listing international sovereign bonds after World War II-including notably those of apartheid-era South Africa, beginning in 1952 - but lost market share beginning in the 1980s. Currently, only three jurisdictions besides Luxembourg (Ireland, London, and Singapore) retain a material share of the market.

Figure 3 reports by year the aggregate number of bonds listed on the top ten exchanges, assuming all listed bonds remain outstanding until maturity. We again observe Luxembourg becoming and remaining the dominant exchange throughout the 1980-2015 period, effectively eliminating all of its historical competitors other than London. Germany, for example, commanded a sizable market share of sovereign listings up to approximately 1990, after which it fell out of favor almost entirely, following the adoption of the Euro. ${ }^{8}$ Similarly, we find that Switzerland was one of the first jurisdictions to begin listing international sovereign bonds after World War II—including notably those of apartheid-era South Africa, beginning in 1952—but lost market share beginning in the 1980s. Currently, only three jurisdictions besides Luxembourg (Ireland, London, and Singapore) retain a material share of the market.

\section{Figure 3: Number of bonds currently listed per year, 1945-2015}

\footnotetext{
${ }^{8}$ The overall growth of the sovereign-debt market made evident by Figure 3 would be even more staggering if reported in inflation-adjusted dollars (rather than by number of issuances), since offerings have also increased dramatically in size over the sample period, from in the range of one hundred million dollars in the first thirty years of the market to multi-billion-dollar offerings in the current era.
} 


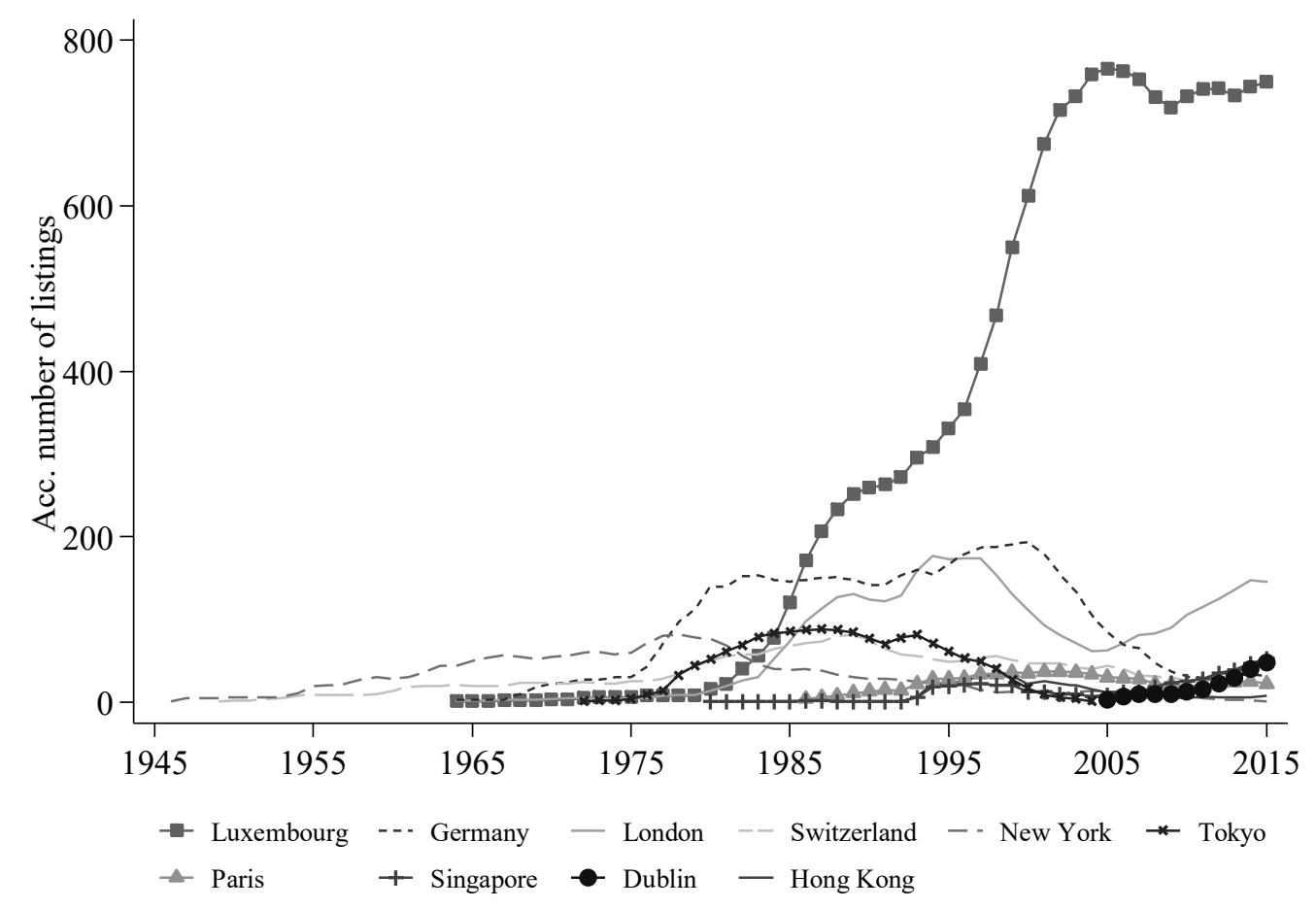

New York's decline as a listing jurisdiction coincides with the birth of the Eurobond market, which was expressly designed to allow non-U.S. issuers to avoid the regulatory burden of the U.S. securities laws while raising funds in dollars (Fuller, 2012). The first Eurobond issue in 1963, by the quasi-sovereign Autostrade, was listed on the London Stock Exchange but traded in several financial centers simultaneously, which became a key feature of Eurobonds. The Eurobond market is thus viewed as the first truly international capital market, in which the jurisdiction of the issuer and the investors, the listing exchange, the currency, and the trading venue(s) became increasingly independent from one another.

To our knowledge, the literature is silent as to what prompted sovereign issuers to shift their listings to Luxembourg when the Eurobond market got its second wind in the 1980s. While Luxembourg is known as something of a tax haven for corporations within the EU, no such tax advantage applies to sovereign bonds, which in the case of Eurobonds have always paid gross interest (that is, without withholding tax on behalf of the issuer's jurisdiction) regardless of the listing jurisdiction. Initially, there may have been advantages to listing in the same jurisdiction as the bonds' clearing agent: one of the two major European clearing systems, Cedel (now Clearstream), was founded in Luxembourg in 1971. It appears that Luxembourg's ascendancy as a listing jurisdiction for sovereign debt is attributable to a combination of chance and 
opportunism. In discussions with senior officers of the Luxembourg Stock Exchange, we were told that the Exchange was first put on the map when major international and supra-national organizations began issuing there, by virtue of Luxembourg's status as one of the seats of government for the European Economic Community. Thereafter, according to our panel of sovereign-debt lawyers, Luxembourg attracted listings simply by adopting significantly more permissive listing standards and charging lower fees than the other major exchanges at the time, a view that is at odds with the bonding hypothesis.

\subsection{The Preferences of Different Types of Issuers}

While the overall shifts from New York and other jurisdictions to Luxembourg are unmistakable, it is unclear from Figure 3 whether these shifts were distributed evenly across issuers of differing credit risk. Figure 4 depicts for each decade from 1960 onwards the relative market share of the top four exchanges and Ireland by category of Standard and Poor's long-term

foreign currency debt rating. ${ }^{9}$ (Although its market share over the full period is negligible, the Irish Stock Exchange is currently the fastest-growing exchange for new sovereign listings. ${ }^{10}$ )

\footnotetext{
${ }^{9}$ For this purpose, we aggregate the bond ratings into only seven categories (AAA, AA, A, BBB, BB, B, and CCC), folding in ratings categories with "pluses" and "minuses."

${ }^{10}$ The Irish Stock Exchange (ISE) was simply a branch of the London Stock Exchange until 1995, when it began operating as an independent exchange. The ISE listed its first international debt offering in 2000.
} 
Figure 4: Share of listings on the top exchanges, by rating, 1960-2015
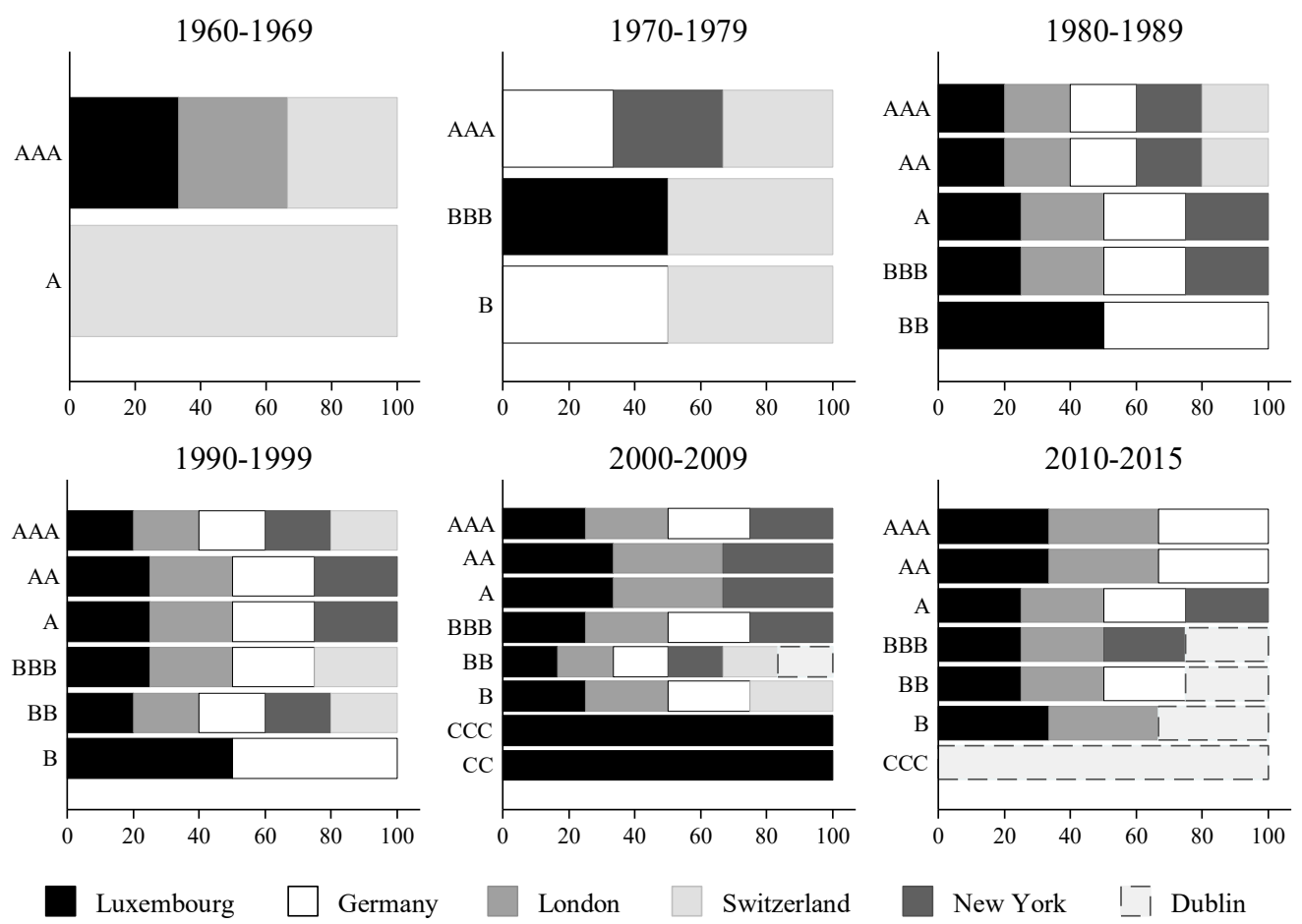

Two phenomena stand out. First, the average quality of international sovereign debt issuances has declined significantly since 1960, when only top-rated (A to AAA) sovereigns listed on foreign exchanges. Today, the international market's appetite for risk has increased significantly, with issuers of all categories of credit risk appearing on the major exchanges. Second, in recent decades there is no clear pattern of lower-rated and higher-rated issuers clustering in different exchanges. Luxembourg and London both attract issuers across a broad risk spectrum, while the increasingly popular Irish Stock Exchange currently appeals disproportionately to lower-rated issuers (as shown in the bottom right corner of Figure 4). ${ }^{11}$ Because both high-quality and low-quality sovereign issuers have for the most part converged on Luxembourg, the indications are of a pooling rather than a separating equilibrium in sovereign debt listings, which is potentially in tension with the bonding hypothesis.

\subsection{The Decline of Multi-Listing}

\footnotetext{
${ }^{11}$ Prior to the $1990 \mathrm{~s}$, there was a relatively clear dichotomy. In the post-War period, New York (until the early 1980s) followed by Luxembourg attracted the lowest quality (highest-yield) issuances. By contrast, Switzerland was the exchange of choice for the highest-quality (lowest-yield) issuances until the mid1980s, at which point Luxembourg and London captured much of its market.
} 
Returning to Figure 1, we observe another historical change in listing patterns for sovereign debt. For several decades during the post-War period, roughly 1975-2000, a number of sovereigns listed their bonds on not just one but multiple foreign exchanges. This was done in one of two ways. First, a sovereign could list the very same bond on multiple foreign exchanges simultaneously. In 1994, for example, Finland listed a U.S.-dollar bond simultaneously on the Luxembourg, Hong Kong, and Singapore exchanges. Second, a sovereign might issue multiple bonds on different exchanges over a relatively short period of time, generally according to the bonds' currency. In the 1980s, for instance, Mexico repeatedly issued Swiss franc bonds on the Swiss exchanges, Peso-denominated bonds in Buenos Aires, and so forth. Both such forms of multi-listing have virtually disappeared in the last decade. The practice today is to list bonds aimed at the international market on a single exchange (which, in turn, is most likely to be Luxembourg), regardless of the currency of issuance.

The erstwhile phenomenon of multi-listing raises several possibilities. First, under the bonding hypothesis, subjecting oneself to the rules of not one, but multiple, foreign exchanges may have been viewed as a particularly credible signal of quality. In that case, the decline of multi-listing in favor of listing solely in Luxembourg could suggest either (1) that Luxembourg now lends issuers so much credibility that they no longer need to incur the expense and inconvenience of listing on multiple exchanges (a hypothesis that we reject in Part 4) or (2) that exchange listings today are no longer viewed as a signal of quality and good behavior, whether because the exchanges' listing standards have declined by historical standards or because another institution such as the rating agencies emerged to provide a comparable function.

Second, in a story more in line with liquidity enhancement than bonding, multi-listing may have been viewed as the best means of accessing investors in different jurisdictions. (A single sovereign listing otherwise identical bonds in different currencies on different exchanges (according to currency) appears more in keeping with the liquidity hypothesis than the bonding hypothesis.) If so, the decline of multi-listing suggests that barriers to cross-border investing have indeed lessened, whether through regulatory changes or private ordering. More broadly, the decline of multi-listing may have parallels to the recent decline in cross-listing by multinational firms: after a surge in foreign firms choosing to cross-list in the U.S. during the 1980s and early 1990s, de-listings and de-registrations by foreign firms in the U.S. have outpaced new crosslisting firms (Karolyi 2012). 


\section{Regression Analysis and Results}

\subsection{Yield Spreads Model}

The choice of whether and where to list sovereign bonds is made prior to issuance, and is typically featured on the very first page of the bond prospectus or offering circular made available to investors. Thus, if sovereigns' listing choices are motivated by bonding, we would expect the chosen exchange to affect the bonds' yield at issuance, all else equal. ${ }^{12}$ For reasons discussed in Part 1, we test for differences in yield among bonds listed on the different major securities exchanges, rather than for differences in yield between listed and unlisted bonds.

The ideal experiment would involve comparing the yields on bonds issued by sovereigns of identical observable credit risk, issued at precisely the same time and with identical contract terms and other features, but listed on different exchanges. In practice, however, we must rely on observational data with considerable heterogeneity in issuer and bond characteristics. Our sample of bond issuances covers a wide range of issuer credit ratings, issue dates, maturities, principal amounts, currencies, and contract terms, and we would expect each of these factors to have a greater effect on the yield at issuance than the choice of exchange. We are aided in our task, however, by the fact that, as shown in Part 3, even sovereigns that tend to list on a single exchange do occasionally switch to a different exchange (while their bond contracts and credit risk remain constant), and many sovereigns have chosen to issue on multiple different exchanges simultaneously or within a relatively short period of time.

Using our sample of pooled cross-sectional data, we examine the effect of listing on a specific stock exchange on the sovereign's cost of capital under the following model:

$$
y_{i j}=\beta_{1} \operatorname{LISTING}_{i}+\beta_{2} X_{i}+\varepsilon_{i}
$$

where each observation is a separate bond issue $i$ by national sovereign $j$, the dependent variable is the spread between the yield at issuance of bond $i$ and the yield on a U.S. Treasury bond with

\footnotetext{
${ }^{12}$ This assumes, of course, that investors price the expected bonding benefits of an exchange listing. Although the market for international sovereign debt is dominated by large institutional investors, pricing is likely less efficient than in the market for corporate debt (e.g., Choi and Gulati 2016). In the absence of a price effect, however, bonding would not be a plausible motivation for listing.
} 
the same maturity and issued on the same day (our proxy for the risk-free rate), and $\mathrm{X}$ is a vector of control variables described below.

Our variables of interest are the nine indicator variables (LISTING) for each of the top ten listing jurisdictions over the full 1945-2015 period other than Luxembourg. Luxembourg is set as the base jurisdiction in the regressions. Thus, a positive (negative) coefficient on one of the LISTING variables indicates that the exchange is associated on average with a higher (lower) yield spread than Luxembourg, all else equal. We also report the F-statistics and corresponding p-values for the hypothesis that the coefficients on the LISTING variables are all equal to zero. Our regression sample is limited to post-1986 issuances-coinciding with the resurgence of the international sovereign-debt market — as we require a complete daily (interpolated) yield curve for U.S. Treasuries. This yields a final sample size of 4,226 issues. We exclude individual exchanges from any regression for which the exchange would have fewer than ten observations.

We include the following control variables to proxy for other factors affecting bond yields. As our primary control for observable credit risk, we include indicator variables for each S\&P ratings category for issuers' long-term foreign-currency credit risk. To control for other contract terms and bond features that should affect yield spreads but might not be fully captured in the credit ratings, we include the bond's maturity/tenor, principal amount issued (natural logarithm), and governing law (following Bradley et al., 2016). To control for currency risk, we include indicator variables for each currency in the sample. Finally, we include the lagged CBOE's volatility index (or VIX) to control for the fact that yield spreads vary over time due to global factors. In all of the specifications reported below, the coefficients on the S\&P ratings categories were all significant and of the expected sign and relative magnitude. Standard errors are clustered at the issuer level.

Table 5 reports the results of our OLS regressions for the full sample of sovereign-bond issuances, from 1986 through 2015. We consider different specifications, including a baseline OLS model, and OLS with issuer and/or year fixed effects. Using the full set of control variables (columns (4) through (7)), including in particular credit ratings, currency, and governing law, none of the coefficients for New York or the major European exchanges is significant at the 5\% level. The lone exception (in column (5)) is Paris, which appears to provide on average a 51basis-point reduction in yield relative to listing in Luxembourg. Tellingly, however, Paris is no longer competitive today in attracting sovereign listings. The top Asian exchanges-Singapore, 
Tokyo, and Hong Kong, do show significant coefficients under various specifications, but of this group only Singapore continues to attract new listings today. Neither of the current top jurisdictions (London and Dublin) is significant relative to Luxembourg at even the $10 \%$ level. Nonetheless, the F-test indicates that the coefficients on the top ten jurisdictions are jointly significant at the $5 \%$ level in all specifications other than columns (6) and (7), with the result likely driven by the Asian exchanges.

Interpreting the results for a thirty-year sample poses certain conceptual difficulties.

Table 6 reports the results of the same OLS regressions using separate subsamples for each decade. The results for the current decade (column (6)) show no significant effects on yield relative to Luxembourg from any of the other listing jurisdictions, and we cannot reject the null hypothesis that all of the coefficients on the listing variables are equal to zero. In prior decades, Switzerland (in the 1980s) and Paris and Hong Kong (in the 1990s) are associated with significant reductions in yield relative to Luxembourg, potentially as a result of a bonding effect, but none of these jurisdictions retains meaningful market share today.

Finally, Table 7 reports the results of the same OLS regressions, limited only to U.S.dollar and euro issuances, in order to rule out the possibility that inflation in the non-major currencies affected the results for the full sample. Once again, none of the coefficients on the listing variables is statistically significant at even the $10 \%$ level in the current decade (column (5)), with the notable exception of Singapore, which is associated with a large and significant reduction in yield. Using the full thirty-year sample (columns (1)-(4)), listing in New York is variously associated with a significant reduction in yield relative to Luxembourg. This result is striking: while the New York Stock Exchange may well have provided a bonding benefit in the past, it has been abandoned entirely by sovereign issuers for over a decade.

\subsection{Yield Premium Model}

OLS regressions using the full sample of sovereign-bond issuances have two limitations: (1) there is considerable heterogeneity across issuers, credit ratings, currencies, maturities, and issue dates; and (2) the listing variables are unbalanced, given Luxembourg's dominant market share relative to any other individual listing jurisdiction, particularly in the current decade. In this section, we attempt to mitigate both concerns by estimating a model that groups bonds according to key parameters and uses the yield differential relative to Luxembourg-listed bonds as the independent variable. 
We begin by grouping all bonds having the same credit rating, currency, maturity, and issue date. For each bond listed on one of the top ten exchanges other than Luxembourg, we define the bond's yield premium relative to Luxembourg-listed bonds as:

$$
\text { Premium }_{i}=Y_{i, t, m, c, r}^{\text {Others }}-\bar{Y}_{t, m, c, r}^{L u x}
$$

where $Y_{i, t, m, c, r}^{\text {Others }}$ is the observed yield at issuance of bond $i$, issued in year $t$, with a maturity of $m$

years, in currency $c$, by a sovereign with long-term foreign-currency credit rating $r$, and $\bar{Y}_{t, m, c, r}^{L u x}$ is the average yield (weighted by principal amount) of all Luxembourg-listed bonds having the same issue year, maturity, currency, and sovereign credit-rating.

We then estimate the following model with OLS regressions:

$$
\text { Premium }_{i}=\beta_{1} \text { LISTING }_{i}+\beta_{2} X_{i}+\varepsilon_{i}
$$

where the independent variables of interest LISTING are our indicator variables for the top listing jurisdictions other than London (which is set as the base jurisdiction here) and Luxembourg, and $X$ is the same vector of controls as in the previous regressions.

Table 8 reports the regression results. We run different specifications (year fixed effects, issuer fixed effects, and issuer and year fixed effects), and use the full sample as well as subsamples for recent decades and for euro and dollar issuances. Once again, we observe significant coefficients only for jurisdictions (such as Germany and Switzerland) that were historically important but do not currently attract sovereign listings, with the surprising exception of Singapore. Overall, we fail to find a consistent yield premium or penalty associated with the major exchanges, particularly for the current decade, thus confirming the results of Tables 5 through 8 .

\subsection{Discussion of Results}

Overall, we find no consistent evidence that a sovereign bond's listing jurisdiction affects the yield at issuance. This result should be qualified in several respects, however. First, our modeling choice and reliance on observational data raise concerns about endogeneity that could bias the regression results. If listing plays a bonding role, it serves as a signal with respect to credit risk that is otherwise unobservable by investors. It could be, however, that an issuer's choice of listing jurisdiction is also motivated by components of credit risk already known to investors - and therefore already incorporated into yield — which would render the indicator 
variables for the bonds' listing jurisdiction endogenous. If it were the case that issuers' observable credit risk drove listings, however, we might expect at least some instances of issuers shifting their listing jurisdiction to occur contemporaneously with changes in such issuers' credit rating. We were unable to identify any such synchrony in the data, even accounting for inertia and delay. Nonetheless, we cannot rule of the potential for endogeneity in the model. ${ }^{13}$

The second qualification relates to the implication of our results for the bonding hypothesis. Because we consider only differences among the exchanges, as opposed to differences between listed and unlisted bonds, the absence of an association between yield and listing jurisdiction could be explained in one of two ways: (1) listing does not perform any bonding function; or (2) listing does provide bonding, but all of the top exchanges provide the same level of bonding. There are several reasons to reject the second proposition in favor of the first.

First, we reviewed the listing requirements applicable to sovereign-debt issuers in each of the top ten listing jurisdictions. While it is true that the exchanges differ very little today in their listing requirements for sovereign debt, this is precisely because they effectively impose only trivial requirements (summarized in Table 9 for the top five exchanges). None of the jurisdictions that we considered imposes material continuing disclosure requirements on sovereign issuers, in marked contrast to requirements for corporate equity issuers, for example. Further, the stated requirements for initial disclosure, if any, are largely misleading. The European exchanges, for example, require non-EEA issuers to provide a prospectus satisfying the EU's Prospectus Directive. Putting aside that the Directive's substantive requirements are minimal for sovereign issuers, a prospectus compliant with the Directive is required for any public offering to EU residents, regardless of where such bonds are listed. In other words, sovereigns listing on the Singapore Exchange are equally subject to the EU Prospectus Directive if any of their bonds will be offered to EU residents.

Second, the top exchanges' listing fees for sovereign debt issuances are also inconsistent with a bonding story. The listing fees for the top five listing jurisdictions (also reported in Table

\footnotetext{
${ }^{13}$ In theory, selection effects could also bias the results, in that sovereign issuances are non-random. Most sovereigns seek to time the markets by issuing only when yields are low, whereas the highest-quality sovereigns pre-commit to issuing on a fixed schedule. In practice, however, our regression sample includes only the former category of sovereigns, and this group should be uniformly affected by any such selection bias.
} 
9), for example, do not exceed US $\$ 20,000$ in aggregate for sovereign debt, and most are well below this. Such amounts pale in comparison to the typical fees paid to the underwriters and credit rating agencies, rendering the notion that such exchanges provide unique screening and monitoring services largely implausible. ${ }^{14}$

Third, in reviewing data provided by the Luxembourg Stock Exchange, we were unable to find a single instance of a bond being delisted as a result of a payment default or violation of a listing standard among the 2,180 unique sovereign-debt issuances listed there since 1945, which one would anticipate if Luxembourg were committed to monitoring issuers.

Fourth, we examined the effects of an exogenous shock that prompted several issuers to change their listing jurisdiction, absent any change in credit risk. When the EU's Prospectus Directive (2003/71/EC) came into effect in 2005, it applied uniformly to all public offerings in the EU, regardless of listing jurisdiction. Thus, the impact (if any) on bonding would have been the same for all exchanges in the EU. Nonetheless, we find that seven of the forty-eight sovereigns with bonds listed in Luxembourg at the time (Croatia, Finland, Hungary, Israel, Sweden, Ukraine, and Uruguay) shifted their listings to London or Dublin during the transition period - an abnormally high rate of change. According to our panel of sovereign-debt lawyers, the Luxembourg Stock Exchange was uncharacteristically slow to implement the requirements of the Prospectus Directive relative to London and Dublin. This suggests that, contrary to the bonding hypothesis, the speed of getting to market is a major motivation for selecting and switching exchanges. In fact, two countries (Croatia and Uruguay) eventually switched back to Luxembourg after the Directive was fully implemented.

Finally, if the fact of listing and the precise listing jurisdiction were important to sovereign-bond investors, we would expect bond contracts to reflect this. Instead, we were unable to identify a single prospectus in our sample in which the issuer's failure to obtain or maintain an exchange listing constituted an event of default. To be sure, sovereign-bond prospectuses routinely state that the issuer has applied to list the bonds on a particular exchange, which can be viewed as an implicit promise to list. Yet in the absence of any related covenants or

\footnotetext{
${ }^{14}$ In the same vein, the Singapore Exchange and the Irish Stock Exchange both prominently market their swift review periods for debt listing applications (of one and three business days, respectively). http://www.sgx.com/wps/portal/sgxweb/home/listings/listing-debt-securities; http://www.ise.ie/ProductsServices/Listing-Debt/; (last visited, Oct. 10, 2016).
} 
events of default in the bond indenture, there is no penalty whatsoever for failure to do so, and nothing prevents the issuer from either switching exchanges or delisting entirely.

We therefore conclude that there is insufficient evidence to support the bonding hypothesis in this market: investors today do not appear to reward or punish sovereigns for their choice of securities exchange.

\section{Alternative Hypotheses}

If the bonding hypothesis does not hold, then the listing puzzle remains: why do most sovereigns choose to list their international bonds on a stock exchange, and how do they select from among the available jurisdictions? If listing on an exchange does not increase an issuer's credibility with investors, why go to the trouble? While listing fees alone are often negligible, the need to involve lawyers, listing agents, and bankers renders the process costly in terms of both time and expense. Yet as a general matter, there is no legal requirement for sovereigns to list on an exchange in order to sell their bonds internationally. In this section, we briefly address some possible explanations for the listing puzzle.

To this end, we contacted senior lawyers at every one of the twelve New York- and London-based law firms with a significant share of international sovereign-debt transactions (as reported in Bradley et al., 2014). Our sample of 53 individuals was taken from the list of elite lawyers who participated in the recent (2011-2015) efforts lead by the IMF, the ICMA (International Capital Markets Association) and the Bank of England to reform sovereign-debt contract provisions. We sent each individual an email containing Figure $\mathbf{3}$ as an attachment and asking for their reaction to the charted listing patterns, as well as their explanation for why sovereigns list and where they do so. We received substantive responses from 44 individuals, for an overall response rate of $83 \%$.

Most notably, not a single respondent mentioned bonding or credibility as an explanation for sovereign-bond listings. Instead, the responses were virtually unanimous in describing the task of obtaining an exchange listing for an international bond issuance as a "check-the-box" item and in pointing to the speed and ease of the listing process as the crucial differentiator between the exchanges. The following response was typical:

"Investors generally do not care where [sovereign bonds] are listed, as long as they are listed somewhere. Since it is a box-checking point for investors, and issuers know this, issuers have begun to look for even easier and less costly places to list." 
Yet noting that investors expect sovereign issuers to list begs the question. What, then, is the purpose of listing sovereign bonds? We discuss three possibilities below: (1) inertia; (2) advisor agency costs; and (3) investor restrictions.

\subsection{Inertia}

Both the decision to list on an exchange and sovereigns' particular choice of exchange could in theory be the result of pure inertia. If stock exchanges historically added value as a bonding mechanism for issuers, perhaps issuers have been slow to recognize that they no longer do so and simply persist in the practice of obtaining a listing and with the same exchange that they have always used. After all, there is evidence of considerable stickiness or inertia with respect to various contractual terms in sovereign bonds (e.g., Gulati and Scott 2013). Yet inertia does not appear to be the driving force here. As Figure 1 shows, the most popular listing jurisdiction for sovereign issuers has changed several times in the post-World War II period, indicating that sovereigns' choices, while perhaps slow to update, are not static. More importantly, the market-wide patterns of sovereign listings mask a considerable degree of mobility at the level of the individual issuer. In particular, the period of multi-listing in the 1990s reveals that individual issuers consciously decide both whether to list and where, rather than simply persisting in their historical choices, and at times they switch frequently among exchanges.

In addition, the detailed responses that we received from top lawyers suggest that they regularly engage in thoughtful consideration of the merits of using one exchange over the other and do not feel bound to any one. Several mentioned having switched exchanges on short notice due to slow response times from one exchange's staff. In sum, Luxembourg's dominant market share for sovereign debt likely reflects neither pure inertia nor some unspecified network effect, but rather the fact that Luxembourg has consistently provided a speedy, easy, and predictable listing process for sovereigns over the past thirty years. ${ }^{15}$

\subsection{Advisor Agency Costs}

\footnotetext{
${ }^{15}$ Indeed, Ireland is reportedly drawing away market share from Luxembourg precisely by competing directly on those three characteristics.
} 
A second hypothesis is that exchange listings reflect a small agency cost or collective action problem on the part of the lawyers or underwriters that advise sovereign debt issuers and who, in practice, select an exchange for the offering. Recall that not one of the lawyers in our sample suggested that exchange listings increase sovereigns' credibility vis-à-vis the institutional investors that purchase sovereign bonds, and yet they persist in advising their clients to list. One possibility is that obtaining exchange listings amounts to a simple, verifiable task to justify their fees to clients. The legal fees involved are unlikely to be significant, however-perhaps no more than a few thousand dollars' worth of a junior associate's time. While we have seen no evidence that advisor agency costs drive listing choices, the hypothesis remains to be explored. A more benign possibility is that, even if they suspect that exchange listings offer no value, they are unwilling to deviate out of risk aversion. Law firms have little incentive to be the first-mover in testing the value of listing.

\subsection{Investment Restrictions}

While the bonding hypothesis dominates the recent literature on cross-listing, a second explanation often given for exchange listings is liquidity. A stock exchange gathers vast numbers of buyers and sellers, thus allowing issuers to raise capital at relatively low cost from the many investors that use the exchange. In the cross-border context, the liquidity or market segmentation hypothesis suggests further that foreign firms can access local investors in a particular jurisdiction more cheaply by listing on a major stock exchange in that jurisdiction, due to regulatory restrictions and other information and transaction costs that hinder foreign investment (Stapleton and Subrahmanyam, 1977; Errunza and Losq, 1985). Perhaps, then, sovereign issuers list abroad in order to target investors in particular jurisdictions and to access the liquidity afforded by the major global exchanges.

Such exchanges cannot truly provide liquidity for international sovereign bonds, however, for the simple reason that most such bonds do not trade on the exchanges themselves. Rather, virtually all international sovereign debt is traded over-the-counter directly between financial institutions. Nor do stock-exchange listings help with price-discovery for sovereign bonds, for the very same reason. The share of international sovereign bonds that is actually traded on the exchanges is too small to serve as a public price signal for the remainder of the 
market; instead, sovereign-bond traders can simply refer to their Bloomberg terminals for recent quotes from dealers.

There is a different sense, however, in which listing on an exchange might provide sovereigns with greater liquidity. There is a mantra in the sovereign-debt industry - often repeated by the exchanges themselves - that certain institutional investors such as pension funds or insurance companies are constrained by law or by internal policy to invest some portion of their assets in listed securities. ${ }^{16}$ In fact, this was the explanation most frequently cited by our sample of experts for sovereigns' decision to list. In order to access such investors, sovereigns are prompted to list, even or especially in jurisdictions with no meaningful listing standards, in a form of regulatory arbitrage. If applicable on a large scale, investment restrictions of this sort could account for the seeming "race to the bottom" in listing requirements that we observe among the most popular listing jurisdictions, with the exchanges competing to offer the fastest, least restrictive approval process. ${ }^{17}$ On this point, the following reaction from a lawyer in our sample was typical:

"The norm is that one needs a foreign listing - but no one seems to care that much where it is. The key is that the location has to be quick and easy — and also cheap."

Another described Luxembourg's marketing pitch to sovereign issuers as boiling down to "[c]heap and easy."

We note two remarkable features of this rationale for exchange listings, however. First, in the absence of any bonding benefits, laws or policies confining institutional investors to listed securities fail to serve any obvious purpose. Such requirements lack substance even on their face: as described, they are not limited to exchanges located in specific jurisdictions or meeting specific standards. The implication is that, if they exist, such investment restrictions reflect either poorly designed regulation or voluntary investment policies that may give retail investors a false sense of security.

\footnotetext{
${ }^{16}$ Arthur Cox, a listing agent for the Irish Stock Exchange, reports that "many" institutional investors "are required to hold at least $90 \%$ of their investments in listed securities." http://www.arthurcox.com/wpcontent/uploads/2014/01/Arthur-Cox-Listing-Services-Specialist-Debt-Securities-June-2013.pdf （last visited October 10, 2016).

${ }^{17}$ In contrast, proponents of the bonding hypothesis in the cross-listing literature have modeled the evolution of the major securities exchanges as a "race to the top," with the exchanges competing by increasing their disclosure requirements, for example (Huddart et al., 1999; Coffee, 1999).
} 
Second, although our respondents frequently referred to such investment restrictions as an explanation for sovereigns' listing practices, they did not identify any specific instances, and we have found very few. (Table 10 provides a small sample from across the globe.) Moreover, examples of such restrictions reported by listing agents or in the press commonly prove to be inapplicable, whether because they are no longer in effect; they apply solely to corporate securities; or they require listing on the issuer's domestic exchange, rather than on any foreign exchange. ${ }^{18}$ This raises the possibility that the entire practice of sovereign debt listings rests on what is largely a false belief. And yet, as one of our respondents explained, even if such restrictions do not actually exist, it may nonetheless be rational for an individual sovereign to obtain a listing: as long as market participants believe (as they appear to do) that such restrictions exist, a sovereign that fails to obtain an exchange-listing may be penalized with a higher yield for passing up the additional liquidity. In the absence of an external change, therefore, sovereign listings may therefore persist for some time to come.

\section{Conclusion}

Our dataset brings to the fore several facts about sovereigns' decision to list their bonds on a foreign securities exchange. First, the patterns of where sovereigns choose to list have shifted in waves since World War II. In particular, New York's dominance in the immediate post-War period eventually gave way to Luxembourg, which has been the overwhelming favorite among sovereign issuers for the past thirty years. Second, other than for the most elite issuers, the practice of listing international sovereign bonds on a foreign exchange persists to this day, despite the fact that barriers to cross-border investment are generally thought to be declining and trading in sovereign bonds has moved almost entirely off the exchanges. Third, similarly to the pattern for cross-listings in the U.S. by foreign firms, the practice of listing sovereign bonds on multiple exchanges gained in popularity in the 1990s, but has since fallen out of favor, suggesting that it does not yield measurable benefits for issuers today.

The most frequent academic explanation for listing securities on a foreign exchange, the bonding hypothesis, no longer appears to apply in today's sovereign debt markets. Sovereign issuers of all credit quality have gravitated en masse toward permissive jurisdictions such as

\footnotetext{
${ }^{18}$ Similarly, the provisions in Table 10 relating to withholding taxes are superfluous for sovereign debt, as opposed to corporate debt. Withholding taxes only apply in such jurisdictions to domestically-sourced income, which would not be the case for interest on debt issued by foreign sovereigns.
} 
Luxembourg, London, Ireland, and Singapore, which impose minimal listing requirements on sovereign issuers today. Using our sample of post-World War II international sovereign bonds, we test whether the bonding hypothesis holds in the sovereign-debt market, by examining whether the specific choice of listing jurisdiction affects a bond's yield at issuance. We find little evidence of such an effect today, and conclude that the major stock exchanges no longer perform screening or monitoring roles for sovereign issuances.

Why, then, do most sovereigns choose to list on foreign stock exchanges? The most frequent explanation from market participants is that institutional investors in some jurisdictions may be required to maintain a specified percentage of their investments in listed securities - on any international exchange. Such investment restrictions are increasingly rare in practice, however, and their application to sovereign bonds is puzzling, given the lack of observed bonding effects from sovereign listings.

At bottom, we see little evidence that exchange listing adds value to sovereign debt issuances. If that is so, then the costs associated with obtaining an exchange listing represent a net social-welfare loss. Why does this matter? While the cost of listing on an exchange is relatively small for each issuance, it is surely significant when aggregated over the thousands of sovereign and sub-sovereign offerings over time and around the globe. ${ }^{19}$ With sovereign bonds now traded almost exclusively over the counter, the ties between sovereign issuers and the major securities exchanges are increasingly tenuous. The market may need a final push to sever them. ${ }^{20}$

${ }^{19}$ As a crude approximation, we estimate such costs to be on the order of $\$ 1.65$ billion for 2015 alone. (We estimate an average of $\$ 100,000$ in direct expenses per listed issuance, including the listing fee and annual fees payable to the exchange, the cost of hiring a debt listing agent, and attorneys' fees attributable to obtaining the listing. This amount is then multiplied by 165 (the number of listed bond issuances in our sample in 2015) and then by 100, to approximate the set of sovereign bonds that are (1) issued by subsovereigns (such as municipalities and government agencies) and supra-sovereigns, (2) guaranteed by sovereigns, or (3) issued under local law, all of which are absent or significantly underrepresented in our sample. Indeed, international sovereign debt represents less than $6 \%$ of all sovereign debt issued (see the Bank for International Settlements, BIS Securities Statistics and Syndicated Loans), yet much of this "local" debt is also exchange-listed.

${ }^{20}$ As of the writing of this paper, the EU's new Market Abuse Regulation (MAR) recently took effect (on July 3, 2016), imposing significant continuing disclosure obligations on all financial instruments listed on exchanges in the EU, whether traded on "regulated" or "unregulated" (professional-only) markets. Because our evidence suggests that investors do not value mandatory disclosure requirements for sovereign issuers, we predict that, unless exemptions for sovereign issuers are introduced, this new regulatory regime could provide sufficient impetus for another market-wide shift in listing patterns, with sovereigns either moving to different jurisdictions such as Singapore or foregoing listing entirely. 


\section{References}

Becker, Torbjörn, Anthony Richards, and Yunyong Thaicharoen. 2003. Bond Restructuring and Moral Hazard: Are Collective Action Clauses Costly? Journal of International Economics, 61(1), 127-161.

Bradley, Michael, and Mitu Gulati. 2013. Collective Action Clauses for the Eurozone. Review of Finance, 18(6), 2045-2102.

Bradley, Michael, Irving De Lira Salvatierra, and Mitu Gulati. 2014. Lawyers: Gatekeepers of the sovereign debt market? International Review of Law and Economics, 38(6), 150-168.

Bradley, Michael, Irving Arturo De Lira Salvatierra, and Mitu Gulati. 2016. A Sovereign's Cost of Capital: Go Foreign or Stay Local. Duke Law School Working Paper. Available at:

http://papers.ssrn.com/sol3/papers.cfm?abstract_id=2679077.

Campbell, Kevin and Isaac T. Tabner. 2014. Bonding and the agency risk premium: An analysis of migrations between the AIM and the Official List of the London Stock Exchange. Journal of International Financial Markets, Institutions and Money, 30(5), 1-20.

Chamon, Marcos, Julian Schumacher, and Christoph Trebesch. 2014. Foreign Law Bonds: Can They Reduce Sovereign Borrowing Costs? Working Paper. Available at:

crei.cat/conferences/ICF15/papers/chamon.pdf.

Choi, Stephen J. and Mitu Gulati. 2015. From Pigs to Hogs. Working Paper. Available at: https://papers.ssrn.com/sol3/papers.cfm?abstract_id=2434272.

Choi, Stephen J., Mitu Gulati, and Eric A. Posner. 2011. Pricing Terms in Sovereign Debt Contracts: A Greek Case Study with Implications for the European Crisis Resolution Mechanism. Capital Markets Law Journal, 6(2), 163-187.

Clare, Andrew, and Nicolas Schmidlin. 2014. The Impact of Foreign Governing Law of European Government Bond Yields, City University London, Mimeo.

Coffee, Jr., John C. 1999. The Future as History: The Prospects for Global Convergence in Corporate Governance and its Implications. Northwestern University Law Review, 93(3), 641708.

Coffee, Jr., John C. 2002. Racing Towards the Top? The Impact of Cross-Listings and Stock Market Competition on International Corporate Governance. Columbia Law Review, 102(7), 1757-1831.

Doidge, Craig, 2004. U.S. Cross-listings and the Private Benefits of Control: Evidence from Dual Class Firms. Journal of Financial Economics, 72(3), 519-554. 
Doidge, Craig, G. Andrew Karolyi, and René Stulz. 2004. Why Are Foreign Firms That Are Listed in the U.S. Worth More? Journal of Financial Economics, 71(2): 205-238.

Doidge, Craig, G. Andrew Karolyi, and René Stulz. 2009. Has New York Become Less Competitive Than London in Global Markets? Evaluating Foreign Listing Choices Over Time. Journal of Financial Economics, 91(3), 253-277.

Doukas, John A., and Hafiz Hoque. 2016. Why Firms Favour the AIM When They Can List on Main Market? Journal of International Money and Finance, 60(2), 378-404.

Doukas, John A., and Liu Wang. 2014. Does the Bonding Effect Matter in a More Integrated Capital Market World? Journal of International Money and Finance, 47(10), 162-184.

Eichengreen, Barry, and Ashoka Mody. 2004. Do Collective Action Clauses Raise Borrowing Costs. Economic Journal, 114(495), 247-264.

Errunza, Vihang and Etienne Losq. 1985. International Asset Pricing Under Mild Segmentation: Theory and Test. Journal of Finance, 40(1), 105-124.

Flandreau, Marc. 2013. Sovereign States, Bondholders Committees, and the London Stock Exchange in the Nineteenth century (1827-68): New Facts and Old Fictions. Oxford Review of Economic Policy, 29(4), 668-696.

Flandreau, Marc and Juan H. Flores. 1999. Bonds and Brands: Foundations of Sovereign Debt Markets, 1820-1830. The Journal of Economic History, 69(3), 646-684.

Foerster, Stephen R., and G. Andrew Karolyi. 1999. The Effects of Market Segmentation and Investor Recognition on Asset Prices: Evidence from Foreign Stocks Listing in the United States. Journal of Finance, 54(3), 981-1013.

Fuller, Geoffrey. 2012. The Law and Practice of International Capital Markets, $3^{\text {rd }}$ edition. London: LexisNexis.

Gugiatti, Mark, and Anthony Richards. 2003. Do Collective Action Clauses Influence Bond Yields? New Evidence from Emerging Markets. International Finance, 6(3), 415-447.

Gurkaynak, Refet S., Brian Sack, and Jonathan H. Wright. 2016. The U.S. Treasury Yield Curve: 1961 to the Present. Working Paper. Available at: http://www.federalreserve.gov/econresdata/feds/2006/index.htm.

Huddart, Steven, Hughes, John S., Markus Brunnermeier. 1999. Disclosure Requirements and Stock Exchange Listing Choice in an International Context. Journal of Accounting and Economics, 26(1-3), 237-269.

Karolyi, Andrew G. 2012. Corporate Governance, Agency Problems and International CrossListings: A Defense of the Bonding Hypothesis. Emerging Markets Review, 13(4), 515-547. 
Macey, Jonathan R. and Maureen O'Hara. 2002. The Economics of Stock Exchange Listing Fees and Listing Requirements. Journal of Financial Intermediation, 11(3), 297-319.

Mahoney, Paul G. 1997. The Exchange as Regulator. Virginia Law Review 83(7), 1453-1500.

Michie, Ranald C. 1999. The London Stock Exchange: A History. Oxford: Oxford University Press.

Panizza, Ugo, Sturzenegger, Frederico, and Zeromin Zettelmeyer. 2009. The Economics and Law of Sovereign Debt and Default. Journal of Economic Literature, 47(3), 651-698.

Reese Jr., William A., and Michael Weisbach. 2002. Protection of Minority Shareholder Interests, Cross-Listings in the United States, and Subsequent Equity Offerings. Journal of Financial Economics, 66(1), 65-104.

Gulati, Mitu, and Robert E. Scott. 2013. The three and a half minute transaction: boilerplate and the limits of contract design. Chicago: University of Chicago Press.

Stapleton, Richard C. and Marti G. Subrahmanyam. 1977. Market Imperfections, Capital Market Equilibrium and Corporation Finance. Journal of Finance, 32 (2), 307-19.

Stulz, René. 1999. Globalization, Corporate Finance, and the Cost of Capital. Journal of Applied Corporate Finance, 12(3), 8-25.

Wright, Mark L. J. 2012. Sovereign Debt Restructuring: Problems and Prospects. Harvard Business Law Review, 2(1), 153-198. 
Table 1: Dependent variable: summary statistics

\begin{tabular}{|c|c|c|c|c|c|c|}
\hline & Bonds & Mean. & Median & $\mathrm{SD}$ & Min & $\operatorname{Max}$ \\
\hline \multicolumn{7}{|c|}{ Yield at issuances in \% } \\
\hline Luxembourg & 1861 & 7.2 & 7.0 & 2.9 & 0.4 & 19.3 \\
\hline Germany & 523 & 7.6 & 7.6 & 2.1 & 0.3 & 16.0 \\
\hline London & 415 & 6.5 & 6.4 & 3.2 & 0.1 & 18.5 \\
\hline Switzerland & 160 & 7.2 & 6.9 & 2.5 & 2.8 & 15.6 \\
\hline New York & 199 & 4.8 & 4.8 & 1.6 & 1.3 & 8.4 \\
\hline Tokyo & 152 & 7.1 & 7.0 & 1.3 & 3.5 & 9.4 \\
\hline Paris & 79 & 5.5 & 5.0 & 2.3 & 0.3 & 10.5 \\
\hline Singapore & 71 & 6.0 & 6.0 & 1.7 & 2.1 & 11.6 \\
\hline Dublin & 53 & 6.5 & 6.4 & 1.7 & 2.8 & 10.8 \\
\hline Hong Kong & 39 & 6.2 & 6.5 & 2.1 & 1.9 & 10.9 \\
\hline Overall & 3704 & 7.0 & 6.9 & 2.7 & 0.1 & 19.3 \\
\hline \multicolumn{7}{|c|}{ Spreads in \% (over Treasury rate) } \\
\hline Luxembourg & 1720 & 2.0 & 1.7 & 2.5 & -6.3 & 14.0 \\
\hline Germany & 379 & 0.4 & 0.4 & 3.1 & -5.3 & 10.5 \\
\hline London & 378 & 0.8 & 0.6 & 2.0 & -6.5 & 8.9 \\
\hline Switzerland & 60 & 1.2 & 1.0 & 1.3 & -1.8 & 5.4 \\
\hline New York & 118 & -2.1 & -1.9 & 2.1 & -7.4 & 3.1 \\
\hline Tokyo & 138 & -2.1 & -2.0 & 1.9 & -6.4 & 2.0 \\
\hline Paris & 76 & -0.1 & -0.3 & 1.2 & -2.7 & 2.9 \\
\hline Singapore & 60 & 2.2 & 2.2 & 2.1 & -2.7 & 8.0 \\
\hline Dublin & 52 & 3.9 & 3.9 & 2.2 & 0.2 & 8.4 \\
\hline Hong Kong & 36 & 0.8 & 0.6 & 1.2 & -3.3 & 3.4 \\
\hline Overall & 3160 & 1.2 & 1.0 & 2.7 & -7.4 & 14.0 \\
\hline
\end{tabular}


Table 2: Distribution of control variables

\begin{tabular}{lllllllllll}
\hline \hline & $\begin{array}{l}\text { Lux- } \\
\text { embourg }\end{array}$ & $\begin{array}{l}\text { Ger- } \\
\text { many }\end{array}$ & $\begin{array}{l}\text { Lon-don Switzer- } \\
\text { land }\end{array}$ & $\begin{array}{l}\text { New } \\
\text { York }\end{array}$ & Tokyo & Paris & \multicolumn{2}{l}{ Singa- Dublin Hong } \\
pore & Kong \\
\hline Ratings & & & & & & & & & & \\
AAA & 307 & 175 & 166 & 55 & 67 & 10 & 35 & 0 & 0 & 0 \\
AA & 488 & 86 & 181 & 4 & 42 & 15 & 44 & 17 & 0 & 18 \\
A & 191 & 16 & 27 & 2 & 23 & 5 & 0 & 9 & 0 & 0 \\
BBB & 336 & 40 & 39 & 3 & 10 & 19 & 1 & 7 & 6 & 20 \\
BB & 510 & 73 & 25 & 7 & 8 & 6 & 4 & 34 & 18 & 7 \\
B & 257 & 50 & 25 & 7 & 0 & 0 & 0 & 15 & 26 & 0 \\
CCC & 6 & 0 & 0 & 0 & 0 & 0 & 0 & 0 & 2 & 0 \\
CC & 1 & 0 & 0 & 0 & 0 & 0 & 0 & 0 & 0 & 0 \\
\hline Total & 2096 & 440 & 463 & 78 & 150 & 55 & 84 & 82 & 52 & 45 \\
na & 84 & 131 & 40 & 93 & 57 & 97 & 3 & 2 & 1 & 6 \\
& & & & & & & & & & \\
Governing law & & & & & & & & & & \\
England & 1005 & 422 & 38 & 24 & 5 & 50 & 21 & 16 & 0 & 10 \\
France & 18 & 0 & 0 & 0 & 0 & 0 & 28 & 1 & 0 & 3 \\
Germany & 38 & 1 & 346 & 0 & 0 & 0 & 0 & 1 & 0 & 1 \\
Japan & 0 & 0 & 0 & 0 & 0 & 0 & 0 & 0 & 152 & 0 \\
Luxembourg & 34 & 0 & 6 & 0 & 0 & 0 & 0 & 0 & 0 & 0 \\
Malaysia & 0 & 0 & 0 & 0 & 0 & 0 & 0 & 0 & 0 & 2 \\
Netherlands & 1 & 0 & 0 & 0 & 0 & 0 & 0 & 0 & 0 & 0 \\
New Jersey & 1 & 0 & 0 & 0 & 0 & 0 & 0 & 0 & 0 & 0 \\
New York & 838 & 36 & 10 & 2 & 67 & 2 & 0 & 63 & 0 & 33 \\
Portugal & 3 & 1 & 0 & 0 & 0 & 0 & 0 & 0 & 0 & 0 \\
Singapore & 0 & 0 & 0 & 0 & 0 & 0 & 0 & 1 & 0 & 0 \\
Switzerland & 2 & 0 & 0 & 87 & 0 & 0 & 0 & 0 & 0 & 0 \\
local & 201 & 29 & 34 & 14 & 0 & 0 & 38 & 1 & 0 & 2 \\
\hline Total & 2141 & 489 & 434 & 127 & 72 & 52 & 87 & 83 & 152 & 51 \\
na & 39 & 14 & 137 & 80 & 99 & 1 & 0 & 1 & 0 & 0 \\
\hline \hline
\end{tabular}




\begin{tabular}{|c|c|c|c|c|c|c|c|c|c|c|}
\hline & $\begin{array}{l}\text { Lux- } \\
\text { embourg }\end{array}$ & $\begin{array}{l}\text { Ger- } \\
\text { many }\end{array}$ & $\begin{array}{l}\text { Lon- } \\
\text { don }\end{array}$ & $\begin{array}{l}\text { Switz } \\
\text { land }\end{array}$ & $\begin{array}{l}- \text { New } \\
\text { York }\end{array}$ & Tokyo & Paris & $\begin{array}{l}\text { Singa- } \\
\text { pore }\end{array}$ & Dublin & $\begin{array}{l}\text { Hong } \\
\text { Kong }\end{array}$ \\
\hline \multicolumn{11}{|c|}{ Currency } \\
\hline AED & 0 & 0 & 1 & 0 & 0 & 0 & 0 & 0 & 0 & 0 \\
\hline ARS & 2 & 0 & 0 & 0 & 0 & 0 & 0 & 0 & 0 & 0 \\
\hline ATS & 4 & 0 & 0 & 0 & 0 & 0 & 0 & 0 & 0 & 0 \\
\hline AUD & 12 & 0 & 7 & 1 & 0 & 0 & 0 & 0 & 0 & 0 \\
\hline BRL & 10 & 0 & 0 & 0 & 0 & 0 & 0 & 0 & 0 & 0 \\
\hline CAD & 18 & 0 & 18 & 0 & 0 & 0 & 0 & 0 & 0 & 0 \\
\hline $\mathrm{CHF}$ & 5 & 0 & 0 & 0 & 206 & 0 & 0 & 0 & 0 & 0 \\
\hline CLP & 4 & 0 & 0 & 0 & 0 & 0 & 0 & 0 & 0 & 0 \\
\hline $\mathrm{CNY}$ & 0 & 0 & 0 & 0 & 0 & 0 & 0 & 1 & 0 & 0 \\
\hline $\mathrm{COP}$ & 12 & 0 & 0 & 0 & 0 & 0 & 0 & 0 & 0 & 0 \\
\hline CZK & 4 & 0 & 0 & 0 & 0 & 0 & 0 & 0 & 0 & 0 \\
\hline DEM & 31 & 469 & 4 & 0 & 0 & 0 & 0 & 1 & 0 & 1 \\
\hline DKK & 14 & 0 & 2 & 0 & 0 & 0 & 0 & 0 & 0 & 0 \\
\hline DRC & 1 & 0 & 0 & 0 & 0 & 0 & 0 & 0 & 0 & 0 \\
\hline EGP & 1 & 0 & 0 & 0 & 0 & 0 & 0 & 0 & 0 & 0 \\
\hline EUR & 529 & 95 & 68 & 2 & 0 & 0 & 43 & 5 & 10 & 4 \\
\hline FRF & 25 & 0 & 5 & 0 & 0 & 0 & 44 & 1 & 0 & 3 \\
\hline GBP & 45 & 0 & 75 & 1 & 0 & 0 & 0 & 0 & 0 & 0 \\
\hline GRD & 8 & 0 & 1 & 0 & 0 & 0 & 0 & 0 & 0 & 0 \\
\hline HRK & 2 & 0 & 0 & 0 & 0 & 0 & 0 & 0 & 0 & 0 \\
\hline HUF & 7 & 0 & 0 & 0 & 0 & 0 & 0 & 0 & 0 & 0 \\
\hline ISK & 2 & 0 & 0 & 0 & 0 & 0 & 0 & 0 & 0 & 0 \\
\hline ITL & 39 & 0 & 5 & 0 & 0 & 0 & 0 & 0 & 0 & 0 \\
\hline JPY & 88 & 0 & 36 & 0 & 0 & 73 & 0 & 3 & 0 & 1 \\
\hline LTL & 1 & 0 & 0 & 0 & 0 & 0 & 0 & 0 & 0 & 0 \\
\hline LUF & 17 & 0 & 0 & 0 & 0 & 0 & 0 & 0 & 0 & 0 \\
\hline MXN & 1 & 0 & 0 & 0 & 0 & 0 & 0 & 0 & 0 & 0 \\
\hline NLG & 7 & 0 & 0 & 0 & 0 & 0 & 0 & 0 & 0 & 0 \\
\hline NOK & 12 & 0 & 7 & 0 & 0 & 0 & 0 & 0 & 0 & 0 \\
\hline NZD & 6 & 0 & 6 & 0 & 0 & 0 & 0 & 0 & 0 & 0 \\
\hline PHP & 3 & 0 & 0 & 0 & 0 & 0 & 0 & 0 & 0 & 0 \\
\hline PLN & 1 & 0 & 0 & 0 & 0 & 0 & 0 & 0 & 0 & 0 \\
\hline PTE & 4 & 0 & 2 & 0 & 0 & 0 & 0 & 0 & 0 & 0 \\
\hline RON & 1 & 0 & 0 & 0 & 0 & 0 & 0 & 0 & 0 & 0 \\
\hline RUB & 0 & 0 & 2 & 0 & 0 & 0 & 0 & 0 & 0 & 0 \\
\hline SEK & 3 & 0 & 10 & 0 & 0 & 0 & 0 & 0 & 0 & 0 \\
\hline SKK & 1 & 0 & 0 & 0 & 0 & 0 & 0 & 0 & 0 & 0 \\
\hline TRY & 11 & 0 & 0 & 0 & 0 & 0 & 0 & 0 & 0 & 0 \\
\hline USD & 1244 & 7 & 247 & 167 & 1 & 0 & 0 & 73 & 43 & 42 \\
\hline UYU & 0 & 0 & 5 & 0 & 0 & 0 & 0 & 0 & 0 & 0 \\
\hline Yen & 0 & 0 & 0 & 0 & 0 & 79 & 0 & 0 & 0 & 0 \\
\hline ZAR & 5 & 0 & 2 & 0 & 0 & 0 & 0 & 0 & 0 & 0 \\
\hline Total & 2180 & 571 & 503 & 171 & 207 & 152 & 87 & 84 & 53 & 51 \\
\hline
\end{tabular}


Table 3: Stock exchanges: number of sovereign bond issuances, 1945-2015

\begin{tabular}{lrrrr}
\hline \hline Stock Exchange & Total Mean per & Maximum & $\begin{array}{r}\text { Date of } \\
\text { per year }\end{array}$ \\
& & Maximum \\
\hline Luxembourg & 2180 & 31.1 & 133 & 1999 \\
Germany (comb.) & 571 & 8.2 & 37 & 1996 \\
London & 503 & 7.2 & 38 & 1993 \\
Switzerland (comb.) & 207 & 3.0 & 10 & 1979 \\
New York & 171 & 2.4 & 15 & 1977 \\
Tokyo & 152 & 2.2 & 19 & 1978 \\
Paris & 87 & 1.2 & 8 & 1997 \\
Singapore & 84 & 1.2 & 14 & 1994 \\
Dublin & 53 & 0.8 & 11 & 2014 \\
Hong Kong & 51 & 0.7 & 18 & 1994 \\
Amsterdam & 42 & 0.6 & 6 & 1997 \\
Milan & 39 & 0.6 & 20 & 1999 \\
Madrid & 32 & 0.5 & 15 & 1997 \\
Vienna & 14 & 0.2 & 3 & 1994 \\
Bangkok & 11 & 0.2 & 5 & 2015 \\
Dubai & 10 & 0.1 & 2 & 2015 \\
Copenhagen & 5 & 0.1 & 2 & 1996 \\
Kuala Lumpur & 4 & 0.1 & 3 & 2015 \\
Buenos Aires & 3 & 0.0 & 2 & 1995 \\
Lisbon & 2 & 0.0 & 1 & 1994 \\
Oslo & 2 & 0.0 & 1 & 1985 \\
Kuwait & 1 & 0.0 & 1 & 1987 \\
Moscow & 1 & 0.0 & 1 & 2010 \\
Quito & 1 & 0.0 & 1 & 2012 \\
\hline Overall & 4226 & 60.4 & 198 & 1999 \\
\hline \hline
\end{tabular}


Table 4: Countries: number of bond issuances, 1945-2015

\begin{tabular}{|c|c|c|c|c|c|}
\hline Country & Freq & Country & Freq & Country & Freq. \\
\hline Austria & 349 & Israel & 17 & Cuba & 3 \\
\hline Sweden & 337 & Thailand & 17 & Gabon & 3 \\
\hline Denmark & 271 & Cyprus & 15 & Macedonia & 3 \\
\hline Italy & 216 & Czech Republic & 14 & Mongolia & 3 \\
\hline Finland & 202 & South Korea & 14 & Nigeria & 3 \\
\hline Argentina & 200 & Dominican Republic & 13 & Paraguay & 3 \\
\hline Turkey & 162 & El Salvador & 13 & Senegal & 3 \\
\hline Brazil & 125 & Slovenia & 13 & United Kingdom & 3 \\
\hline Hungary & 119 & Tunisia & 13 & Zambia & 3 \\
\hline Mexico & 118 & Morocco & 12 & Albania & 2 \\
\hline Belgium & 111 & Kazakhstan & 11 & Algeria & 2 \\
\hline Greece & 108 & Laos & 11 & Angola & 2 \\
\hline Ireland & 107 & Pakistan & 11 & Bosnia and Herzeg. & 2 \\
\hline New Zealand & 107 & Bahrain & 10 & Congo & 2 \\
\hline Australia & 94 & Bulgaria & 10 & Georgia & 2 \\
\hline Portugal & 92 & Qatar & 10 & Grenada & 2 \\
\hline Colombia & 84 & Sri Lanka & 10 & Iran & 2 \\
\hline Lebanon & 77 & Trinidad and Tobago & 9 & Jordan & 2 \\
\hline Philippines & 76 & Barbados & 8 & Namibia & 2 \\
\hline Poland & 69 & Ecuador & 8 & Netherlands & 2 \\
\hline Venezuela & 68 & Egypt & 8 & Qatar Suku & 2 \\
\hline Spain & 63 & Latvia & 8 & Seychelles & 2 \\
\hline South Africa & 60 & Dubai Suku & 7 & Armenia & 1 \\
\hline Norway & 56 & Indonesia Suku & 7 & Azerbaijan & 1 \\
\hline Canada & 48 & Japan & 7 & Bolivia & 1 \\
\hline Uruguay & 44 & Yugoslavia & 7 & Cameroon & 1 \\
\hline Malaysia & 42 & Hong Kong Suku & 6 & Cote d'Ivoire & 1 \\
\hline China & 39 & Malaysia Suku & 6 & Czechoslovakia & 1 \\
\hline Indonesia & 38 & Montenegro & 5 & Dem. Rep. of Congo & 1 \\
\hline Iceland & 37 & Singapore & 5 & Estonia & 1 \\
\hline Panama & 37 & Aruba & 4 & Ethiopia & 1 \\
\hline Lithuania & 34 & Belarus & 4 & Fiji & 1 \\
\hline Ukraine & 32 & Belize & 4 & Gibraltar & 1 \\
\hline Slovak Republic & 27 & Ghana & 4 & Honduras & 1 \\
\hline Jamaica & 26 & Guatemala & 4 & Liechtenstein & 1 \\
\hline Russia & 26 & Kenya & 4 & Mauritius & 1 \\
\hline Croatia & 24 & United Arab Emirates & 4 & Moldova & 1 \\
\hline Romania & 24 & United States & 4 & Oman & 1 \\
\hline Costa Rica & 23 & Vietnam & 4 & Rwanda & 1 \\
\hline Peru & 21 & Bahamas & 3 & Turkey Suku & 1 \\
\hline Chile & 18 & & & & \\
\hline
\end{tabular}


Table 5: OLS results: full sample, 1986-2015

\begin{tabular}{|c|c|c|c|c|c|c|c|}
\hline & $\begin{array}{l}(1) \\
\text { Spreads }\end{array}$ & $\begin{array}{l}(2) \\
\text { Spreads }\end{array}$ & $\begin{array}{l}(3) \\
\text { Spreads }\end{array}$ & $\begin{array}{l}\text { (4) } \\
\text { Spreads }\end{array}$ & $\begin{array}{l}(5) \\
\text { Spreads }\end{array}$ & $\begin{array}{l}(6) \\
\text { Spreads }\end{array}$ & $\begin{array}{l}(7) \\
\text { Spreads }\end{array}$ \\
\hline \multicolumn{8}{|c|}{ Listing places (base: Luxembourg) } \\
\hline Germany & $\begin{array}{l}-1.55^{* * *} \\
(0.17)\end{array}$ & $\begin{array}{l}-0.86^{* * *} \\
(0.18)\end{array}$ & $\begin{array}{l}-0.59^{* * *} \\
(0.13)\end{array}$ & $\begin{array}{l}0.05 \\
(0.20)\end{array}$ & $\begin{array}{l}-0.23 \\
(0.19)\end{array}$ & $\begin{array}{l}0.05 \\
(0.19)\end{array}$ & $\begin{array}{l}-0.14 \\
(0.21)\end{array}$ \\
\hline London & $\begin{array}{l}-1.14 * * * \\
(0.12)\end{array}$ & $\begin{array}{l}-1.18^{* * *} \\
(0.13)\end{array}$ & $\begin{array}{l}-0.28 * * \\
(0.13)\end{array}$ & $\begin{array}{l}-0.08 \\
(0.10)\end{array}$ & $\begin{array}{l}-0.14 \\
(0.13)\end{array}$ & $\begin{array}{l}-0.01 \\
(0.09)\end{array}$ & $\begin{array}{l}0.08 \\
(0.19)\end{array}$ \\
\hline Switzerland & $\begin{array}{l}-4.06 * * * \\
(0.20)\end{array}$ & $\begin{array}{l}-3.84^{* * *} \\
(0.19)\end{array}$ & $\begin{array}{l}-2.44^{* * *} \\
(0.16)\end{array}$ & $\begin{array}{l}-0.60 \\
(0.50)\end{array}$ & $\begin{array}{l}-0.43 \\
(0.51)\end{array}$ & $\begin{array}{l}-0.53 \\
(0.42)\end{array}$ & $\begin{array}{l}-0.67 * \\
(0.37)\end{array}$ \\
\hline New York & $\begin{array}{l}-0.79 * * * \\
(0.17)\end{array}$ & $\begin{array}{l}-0.42 \\
(0.40)\end{array}$ & $\begin{array}{l}-0.48 \\
(0.29)\end{array}$ & $\begin{array}{l}-0.29 \\
(0.22)\end{array}$ & $\begin{array}{l}-0.27 \\
(0.30)\end{array}$ & $\begin{array}{l}-0.29 \\
(0.22)\end{array}$ & $\begin{array}{l}-0.30 \\
(0.40)\end{array}$ \\
\hline Tokyo & $\begin{array}{l}-4.04 * * * \\
(0.17)\end{array}$ & $\begin{array}{l}-3.41 * * * \\
(0.23)\end{array}$ & $\begin{array}{l}-2.65^{* * *} \\
(0.21)\end{array}$ & $\begin{array}{l}2.45^{* * *} \\
(0.50)\end{array}$ & $\begin{array}{l}2.77 * * * \\
(0.59)\end{array}$ & & \\
\hline Paris & $\begin{array}{l}-2.08 * * * \\
(0.15)\end{array}$ & $\begin{array}{l}-2.12 * * * \\
(0.17)\end{array}$ & $\begin{array}{l}-0.40^{* *} \\
(0.19)\end{array}$ & $\begin{array}{l}-0.26 \\
(0.20)\end{array}$ & $\begin{array}{l}-0.51^{* *} \\
(0.20)\end{array}$ & $\begin{array}{l}-0.20 \\
(0.18)\end{array}$ & $\begin{array}{l}0.00 \\
(0.23)\end{array}$ \\
\hline Singapore & $\begin{array}{l}0.26 \\
(0.28)\end{array}$ & $\begin{array}{l}0.26 \\
(0.28)\end{array}$ & $\begin{array}{l}-0.27 \\
(0.19)\end{array}$ & $\begin{array}{l}-0.33^{* *} \\
(0.17)\end{array}$ & $\begin{array}{l}0.32 * \\
(0.18)\end{array}$ & $\begin{array}{l}-0.33^{* *} \\
(0.17)\end{array}$ & $\begin{array}{l}0.70 * * \\
(0.34)\end{array}$ \\
\hline Dublin & $\begin{array}{l}1.93 * * * \\
(0.31)\end{array}$ & $\begin{array}{l}1.98 * * * \\
(0.31)\end{array}$ & $\begin{array}{l}0.35 \\
(0.29)\end{array}$ & $\begin{array}{l}0.40 \\
(0.26)\end{array}$ & $\begin{array}{l}-0.64 * \\
(0.34)\end{array}$ & $\begin{array}{l}0.44^{*} \\
(0.25)\end{array}$ & $\begin{array}{l}-0.18 \\
(0.33)\end{array}$ \\
\hline Hong Kong & $\begin{array}{l}-1.18^{* * *} \\
(0.20)\end{array}$ & $\begin{array}{l}-1.24 * * * \\
(0.21)\end{array}$ & $\begin{array}{l}-0.77 * * * \\
(0.21)\end{array}$ & $\begin{array}{l}-0.71 * * * \\
(0.19)\end{array}$ & $\begin{array}{l}-0.38 \\
(0.24)\end{array}$ & $\begin{array}{l}-0.51^{* * *} \\
(0.19)\end{array}$ & $\begin{array}{l}-0.34 \\
(0.54)\end{array}$ \\
\hline Tenor & & $\begin{array}{l}0.01 \\
(0.01)\end{array}$ & $\begin{array}{l}-0.03 * * * \\
(0.01)\end{array}$ & $\begin{array}{l}-0.01 * \\
(0.01)\end{array}$ & $\begin{array}{l}-0.02 * * * \\
(0.01)\end{array}$ & $\begin{array}{l}-0.00 \\
(0.01)\end{array}$ & $\begin{array}{l}-0.03 * * * \\
(0.01)\end{array}$ \\
\hline Amount issued in USD (log) & & $\begin{array}{l}-0.17 * * * \\
(0.05)\end{array}$ & $\begin{array}{l}-0.25^{* * *} \\
(0.04)\end{array}$ & $\begin{array}{l}0.04 \\
(0.03)\end{array}$ & $\begin{array}{l}0.03 \\
(0.04)\end{array}$ & $\begin{array}{l}-0.06 \\
(0.03)\end{array}$ & $\begin{array}{l}-0.14 * * * \\
(0.04)\end{array}$ \\
\hline Lagged CBOE Volatility Index & & $\begin{array}{l}0.28 * \\
(0.15)\end{array}$ & $\begin{array}{l}0.42^{* * *} \\
(0.13)\end{array}$ & $\begin{array}{l}0.90 * * * \\
(0.09)\end{array}$ & $\begin{array}{l}0.79 * * * \\
(0.09)\end{array}$ & $\begin{array}{l}0.85^{* * *} \\
(0.15)\end{array}$ & $\begin{array}{l}0.24 \\
(0.17)\end{array}$ \\
\hline Constant & $\begin{array}{l}1.97 * * * \\
(0.06)\end{array}$ & $\begin{array}{l}4.65^{* * *} \\
(1.11)\end{array}$ & $\begin{array}{l}4.62 * * * \\
(1.14)\end{array}$ & $\begin{array}{l}-3.76^{* * *} \\
(0.95)\end{array}$ & $\begin{array}{l}-1.23 \\
(1.28)\end{array}$ & $\begin{array}{l}-0.31 \\
(1.06)\end{array}$ & $\begin{array}{l}9.85 * * * \\
(1.49)\end{array}$ \\
\hline Observations & 3,017 & 2,580 & 2,450 & 2,430 & 2,430 & 2,430 & 1,588 \\
\hline R-squared & 0.204 & 0.162 & 0.495 & 0.711 & 0.750 & 0.749 & 0.821 \\
\hline Test for all listing dummies $=0$ & 116.9 & 86.78 & 40.00 & 5.512 & 4.235 & 2.278 & 1.241 \\
\hline p-value & 0 & 0 & 0 & 0.000 & 0.000 & 0.020 & 0.271 \\
\hline Country fixed effects & No & No & No & No & Yes & No & Yes \\
\hline Year fixed effects & No & No & No & No & No & Yes & Yes \\
\hline Comments & & & $\begin{array}{l}\text { includes } \\
\text { dummies for } \\
\text { ratings }\end{array}$ & $\begin{array}{l}\text { includes } \\
\text { dummies for } \\
\text { rating, } \\
\text { governing law } \\
\text { \& currency }\end{array}$ & $\begin{array}{l}\text { includes } \\
\text { dummies for } \\
\text { rating, } \\
\text { governing law } \\
\text { \& currency }\end{array}$ & $\begin{array}{l}\text { includes } \\
\text { dummies for } \\
\text { rating, } \\
\text { governing law } \\
\text { \& currency }\end{array}$ & $\begin{array}{l}\text { includes } \\
\text { dummies for } \\
\text { rating, } \\
\text { governing law } \\
\text { \& currency }\end{array}$ \\
\hline
\end{tabular}


Table 6: OLS results: subsample, by decade

\begin{tabular}{|c|c|c|c|c|c|c|}
\hline & $\begin{array}{l}(1) \\
1980-1989 \\
\text { Spreads }\end{array}$ & $\begin{array}{l}(2) \\
1980-1989 \\
\text { Spreads }\end{array}$ & $\begin{array}{l}(3) \\
1990-1999 \\
\text { Spreads }\end{array}$ & $\begin{array}{l}(4) \\
1990-1999 \\
\text { Spreads }\end{array}$ & $\begin{array}{l}(5) \\
2000-2009 \\
\text { Spreads }\end{array}$ & $\begin{array}{l}(6) \\
2010-2015 \\
\text { Spreads }\end{array}$ \\
\hline \multicolumn{7}{|c|}{ Listing places (base: Luxembourg) } \\
\hline Germany & & & $\begin{array}{l}-0.24 \\
(0.35)\end{array}$ & $\begin{array}{l}-0.26 \\
(0.32)\end{array}$ & $\begin{array}{l}-0.31 \\
(0.23)\end{array}$ & $\begin{array}{l}-0.77 \\
(0.68)\end{array}$ \\
\hline London & $\begin{array}{l}-0.09 \\
(0.41)\end{array}$ & $\begin{array}{l}-0.20 \\
(0.39)\end{array}$ & $\begin{array}{l}-0.35^{*} \\
(0.19)\end{array}$ & $\begin{array}{l}-0.30^{*} \\
(0.17)\end{array}$ & $\begin{array}{l}0.11 \\
(0.22)\end{array}$ & $\begin{array}{l}0.50 \\
(0.58)\end{array}$ \\
\hline Switzerland & $\begin{array}{l}-1.25 * * * \\
(0.36)\end{array}$ & $\begin{array}{l}-1.69 * * * \\
(0.39)\end{array}$ & $\begin{array}{l}-0.21 \\
(0.48)\end{array}$ & $\begin{array}{l}-0.50 \\
(0.49)\end{array}$ & $\begin{array}{l}-0.55 \\
(0.44)\end{array}$ & \\
\hline New York & $\begin{array}{l}-0.39 \\
(0.39)\end{array}$ & $\begin{array}{l}-0.36 \\
(0.36)\end{array}$ & & & & \\
\hline Tokyo & $\begin{array}{l}0.01 \\
(1.48)\end{array}$ & $\begin{array}{l}-1.27 \\
(1.54)\end{array}$ & $\begin{array}{l}5.89^{* * *} \\
(1.10)\end{array}$ & $\begin{array}{l}4.96^{* * *} \\
(0.78)\end{array}$ & & \\
\hline Paris & $\begin{array}{l}-1.00 \\
(0.81)\end{array}$ & $\begin{array}{l}-0.79 \\
(0.83)\end{array}$ & $\begin{array}{l}-1.07 * * * \\
(0.29)\end{array}$ & $\begin{array}{l}-0.89 * * * \\
(0.25)\end{array}$ & $\begin{array}{l}0.15 \\
(0.27)\end{array}$ & $\begin{array}{l}-0.66 \\
(0.68)\end{array}$ \\
\hline Singapore & & & $\begin{array}{l}-0.37 \\
(0.23)\end{array}$ & $\begin{array}{l}-0.05 \\
(0.28)\end{array}$ & $\begin{array}{l}0.96^{*} \\
(0.50)\end{array}$ & $\begin{array}{l}-0.68 \\
(0.68)\end{array}$ \\
\hline Dublin & & & & & $\begin{array}{l}-1.30 * * * \\
(0.36)\end{array}$ & $\begin{array}{l}0.60 \\
(0.52)\end{array}$ \\
\hline Hong Kong & & & $\begin{array}{l}-0.74 * * * \\
(0.27)\end{array}$ & $\begin{array}{l}-0.46^{*} \\
(0.25)\end{array}$ & & \\
\hline Tenor & $\begin{array}{l}-0.02 \\
(0.02)\end{array}$ & $\begin{array}{l}-0.02 \\
(0.02)\end{array}$ & $\begin{array}{l}0.06^{* * *} \\
(0.02)\end{array}$ & $\begin{array}{l}0.06^{* * *} \\
(0.01)\end{array}$ & $\begin{array}{l}-0.03 * * * \\
(0.01)\end{array}$ & $\begin{array}{l}-0.01 \\
(0.01)\end{array}$ \\
\hline Amount issued in USD $(\log )$ & $\begin{array}{l}-0.05 \\
(0.28)\end{array}$ & $\begin{array}{l}0.03 \\
(0.28)\end{array}$ & $\begin{array}{l}-0.06 \\
(0.08)\end{array}$ & $\begin{array}{l}-0.08 \\
(0.07)\end{array}$ & $\begin{array}{l}-0.16^{* * *} \\
(0.06)\end{array}$ & $\begin{array}{l}-0.18 * * * \\
(0.07)\end{array}$ \\
\hline $\begin{array}{l}\text { Lagged CBOE Volatility } \\
\text { Index }\end{array}$ & $\begin{array}{l}-0.69^{*} \\
(0.37)\end{array}$ & $\begin{array}{l}0.28 \\
(0.49)\end{array}$ & $\begin{array}{l}-0.37 \\
(0.23)\end{array}$ & $\begin{array}{l}0.51 \\
(0.37)\end{array}$ & $\begin{array}{l}0.90^{* * * *} \\
(0.21)\end{array}$ & $\begin{array}{l}0.95^{* * * *} \\
(0.26)\end{array}$ \\
\hline Constant & $\begin{array}{l}1.55 \\
(5.71)\end{array}$ & $\begin{array}{l}-3.42 \\
(5.51)\end{array}$ & $\begin{array}{l}1.47 \\
(1.88)\end{array}$ & $\begin{array}{l}0.24 \\
(1.99)\end{array}$ & $\begin{array}{l}3.92 * * * \\
(1.48)\end{array}$ & $\begin{array}{l}9.21 * * * \\
(1.94)\end{array}$ \\
\hline Observations & 189 & 189 & 827 & 827 & 859 & 464 \\
\hline R-squared & 0.825 & 0.840 & 0.755 & 0.797 & 0.861 & 0.903 \\
\hline Test for all listing dummies $=$ & ( 3.417 & 4.963 & 6.465 & 7.130 & 3.570 & 0.813 \\
\hline $\mathrm{p}$-value & 0.006 & 0.000 & 0.000 & 0.000 & 0.002 & 0.541 \\
\hline Country fixed effects & Yes & Yes & Yes & Yes & Yes & Yes \\
\hline Year fixed effects & No & Yes & No & Yes & Yes & Yes \\
\hline Comments & $\begin{array}{l}\text { includes } \\
\text { dummies for } \\
\text { rating, } \\
\text { governing law } \\
\text { \& currency }\end{array}$ & $\begin{array}{l}\text { includes } \\
\text { dummies for } \\
\text { rating, } \\
\text { governing law \& } \\
\text { currency }\end{array}$ & $\begin{array}{l}\text { includes } \\
\text { dummies for } \\
\text { rating, } \\
\text { governing law \& } \\
\text { currency }\end{array}$ & $\begin{array}{l}\text { includes } \\
\text { dummies for } \\
\text { rating, } \\
\text { governing law \& } \\
\text { currency }\end{array}$ & $\begin{array}{l}\text { includes } \\
\text { dummies for } \\
\text { rating, } \\
\text { governing law } \\
\text { \& currency }\end{array}$ & $\begin{array}{l}\text { includes } \\
\text { dummies for } \\
\text { rating, governing } \\
\text { law \& currency }\end{array}$ \\
\hline
\end{tabular}

Robust standard errors in parentheses

$* * * \mathrm{p}<0.01, * * \mathrm{p}<0.05, * \mathrm{p}<0.1$ 
Table 7: OLS results: subsample, USD- and EUR-denominated bonds only

\begin{tabular}{|c|c|c|c|c|c|}
\hline & $\begin{array}{l}1) \\
\text { Full sample } \\
\text { Spreads }\end{array}$ & $\begin{array}{l}\text { (2) } \\
\text { Full sample } \\
\text { Spreads }\end{array}$ & $\begin{array}{l}\text { (3) } \\
\text { Full sample } \\
\text { Spreads }\end{array}$ & $\begin{array}{l}\text { (4) } \\
\text { Full sample } \\
\text { Spreads }\end{array}$ & $\begin{array}{l}(5) \\
2010-2015 \\
\text { Spreads }\end{array}$ \\
\hline \multicolumn{6}{|c|}{ Listing places (base: Luxembourg) } \\
\hline Germany & $\begin{array}{l}0.31 \\
(0.31)\end{array}$ & $\begin{array}{l}0.21 \\
(0.22)\end{array}$ & $\begin{array}{l}-0.01 \\
(0.21)\end{array}$ & $\begin{array}{l}-0.08 \\
(0.21)\end{array}$ & $\begin{array}{l}-0.75 \\
(0.71)\end{array}$ \\
\hline London & $\begin{array}{l}-0.98^{* * *} \\
(0.14)\end{array}$ & $\begin{array}{l}0.11 \\
(0.10)\end{array}$ & $\begin{array}{l}0.10 \\
(0.15)\end{array}$ & $\begin{array}{l}0.05 \\
(0.14)\end{array}$ & $\begin{array}{l}0.48 \\
(0.57)\end{array}$ \\
\hline Switzerland & & & & & \\
\hline Tokyo & & & & & \\
\hline New York & $\begin{array}{l}-1.00^{* * *} \\
(0.16)\end{array}$ & $\begin{array}{l}-0.48^{* *} \\
(0.21)\end{array}$ & $\begin{array}{l}-0.45^{*} \\
(0.23)\end{array}$ & $\begin{array}{l}-0.21 \\
(0.23)\end{array}$ & \\
\hline Paris & $\begin{array}{l}-2.72 * * * \\
(0.14)\end{array}$ & $\begin{array}{l}0.12 \\
(0.19)\end{array}$ & $\begin{array}{l}-0.14 \\
(0.22)\end{array}$ & $\begin{array}{l}-0.16 \\
(0.21)\end{array}$ & $\begin{array}{l}-0.68 \\
(0.71)\end{array}$ \\
\hline Singapore & $\begin{array}{l}0.19 \\
(0.26)\end{array}$ & $\begin{array}{l}-0.31^{*} \\
(0.16)\end{array}$ & $\begin{array}{l}0.39 * * \\
(0.18)\end{array}$ & $\begin{array}{l}0.43 * * \\
(0.18)\end{array}$ & $\begin{array}{l}-3.27 * * * \\
(0.96)\end{array}$ \\
\hline Dublin & $\begin{array}{l}1.79^{* * *} \\
(0.30)\end{array}$ & $\begin{array}{l}0.60^{* *} \\
(0.25)\end{array}$ & $\begin{array}{l}0.09 \\
(0.31)\end{array}$ & $\begin{array}{l}-0.02 \\
(0.30)\end{array}$ & $\begin{array}{l}0.58 \\
(0.52)\end{array}$ \\
\hline Hong Kong & $\begin{array}{l}-1.33^{* * *} \\
(0.21)\end{array}$ & $\begin{array}{l}-0.75^{* * *} \\
(0.21)\end{array}$ & $\begin{array}{l}-0.46^{*} \\
(0.28)\end{array}$ & $\begin{array}{l}-0.43^{*} \\
(0.25)\end{array}$ & \\
\hline Tenor & & $\begin{array}{l}-0.00 \\
(0.01)\end{array}$ & $\begin{array}{l}-0.01^{*} \\
(0.01)\end{array}$ & $\begin{array}{l}-0.01 \\
(0.01)\end{array}$ & $\begin{array}{l}-0.02 \\
(0.01)\end{array}$ \\
\hline Amount issued in USD $(\log )$ & & $\begin{array}{l}0.02 \\
(0.03)\end{array}$ & $\begin{array}{l}0.01 \\
(0.04)\end{array}$ & $\begin{array}{l}-0.08^{*} \\
(0.04)\end{array}$ & $\begin{array}{l}-0.17 * * \\
(0.07)\end{array}$ \\
\hline Lagged CBOE Volatility Index & & $\begin{array}{l}1.42^{* * *} \\
(0.10)\end{array}$ & $\begin{array}{l}1.33^{* * *} \\
(0.10)\end{array}$ & $\begin{array}{l}1.03 * * * \\
(0.17)\end{array}$ & $\begin{array}{l}0.97^{* * *} \\
(0.27)\end{array}$ \\
\hline Constant & $\begin{array}{l}2.15^{* * *} \\
(0.06)\end{array}$ & $\begin{array}{l}-9.14 * * * \\
(0.77)\end{array}$ & $\begin{array}{l}-7.49^{* * *} \\
(1.24)\end{array}$ & $\begin{array}{l}-4.21^{* * *} \\
(1.21)\end{array}$ & $\begin{array}{l}4.81^{* *} \\
(1.93)\end{array}$ \\
\hline Observations & 1,906 & 1,653 & 1,653 & 1,653 & 436 \\
\hline R-squared & 0.085 & 0.678 & 0.741 & 0.768 & 0.900 \\
\hline Test for all listing dummies $=0$ & 73.04 & 4.052 & 2.154 & 1.989 & 3.964 \\
\hline $\mathrm{p}$-value & 0 & 0.000 & 0.036 & 0.053 & 0.002 \\
\hline Country fixed effects & No & No & Yes & Yes & Yes \\
\hline Year fixed effects & No & No & No & Yes & Yes \\
\hline Comments & & $\begin{array}{l}\text { includes } \\
\text { dummies for } \\
\text { rating, } \\
\text { governing law } \\
\text { \& currency }\end{array}$ & $\begin{array}{l}\text { includes } \\
\text { dummies for } \\
\text { rating, } \\
\text { governing law \& } \\
\text { currency }\end{array}$ & $\begin{array}{l}\text { includes } \\
\text { dummies for } \\
\text { rating, } \\
\text { governing law \& } \\
\text { currency }\end{array}$ & $\begin{array}{l}\text { includes } \\
\text { dummies for } \\
\text { rating, governing } \\
\text { law \& currency }\end{array}$ \\
\hline
\end{tabular}

Robust standard errors in parentheses

${ }^{* * *} \mathrm{p}<0.01,{ }^{* *} \mathrm{p}<0.05,{ }^{*} \mathrm{p}<0.1$ 
Table 8: OLS results: yield premium as dependent variable

\begin{tabular}{|c|c|c|c|c|c|c|}
\hline & $\begin{array}{l}\text { (1) } \\
\text { Total Sample } \\
\text { Premium } \\
\end{array}$ & $\begin{array}{l}\text { (2) } \\
\text { Total Sample }\end{array}$ & $\begin{array}{l}\text { (3) } \\
\text { Total Sample }\end{array}$ & $\begin{array}{l}\text { (4) } \\
\text { Total Sample }\end{array}$ & $\begin{array}{l}\text { (5) } \\
2010-2015\end{array}$ & $\begin{array}{l}\text { (6) } \\
2010-2015 \\
\text { USD \& EUR } \\
\text { bonds } \\
\text { Premium }\end{array}$ \\
\hline \multicolumn{7}{|l|}{ Listing places (base: London) } \\
\hline Germany & $\begin{array}{l}1.68 \\
(1.06)\end{array}$ & $\begin{array}{l}-0.07 \\
(0.64)\end{array}$ & $\begin{array}{l}3.53 * * * \\
(0.48)\end{array}$ & $\begin{array}{l}-2.56^{*} \\
(1.39)\end{array}$ & & \\
\hline Switzerland & $\begin{array}{l}-1.21 \\
(0.77)\end{array}$ & $\begin{array}{l}-0.65 \\
(1.00)\end{array}$ & $\begin{array}{l}-1.78 * \\
(0.93)\end{array}$ & $\begin{array}{l}-2.58 * \\
(1.31)\end{array}$ & & \\
\hline \multicolumn{7}{|l|}{ New York } \\
\hline \multicolumn{7}{|l|}{ Tokyo } \\
\hline \multicolumn{7}{|l|}{ Paris } \\
\hline Singapore & $\begin{array}{l}3.31^{* *} \\
(1.38)\end{array}$ & $\begin{array}{l}6.50 * * * \\
(1.06)\end{array}$ & & $\begin{array}{l}9.30 * * * \\
(1.77)\end{array}$ & $\begin{array}{l}-3.01 * * * \\
(0.76)\end{array}$ & $\begin{array}{l}-3.01 * * * \\
(0.76)\end{array}$ \\
\hline Dublin & & & $\begin{array}{l}-2.08 * \\
(1.05)\end{array}$ & & $\begin{array}{l}-2.42 \\
(1.62)\end{array}$ & $\begin{array}{l}-2.42 \\
(1.62)\end{array}$ \\
\hline \multicolumn{7}{|l|}{ Hong Kong } \\
\hline Tenor & $\begin{array}{l}0.05 * * \\
(0.02)\end{array}$ & $\begin{array}{l}0.03 \\
(0.02)\end{array}$ & $\begin{array}{l}0.04 \\
(0.03)\end{array}$ & $\begin{array}{l}0.03 \\
(0.03)\end{array}$ & $\begin{array}{l}0.01 \\
(0.04)\end{array}$ & $\begin{array}{l}0.01 \\
(0.04)\end{array}$ \\
\hline Amount issued in USD (log) & $\begin{array}{l}0.13 \\
(0.15)\end{array}$ & $\begin{array}{l}-0.09 \\
(0.18)\end{array}$ & $\begin{array}{l}0.19 \\
(0.16)\end{array}$ & $\begin{array}{l}-0.14 \\
(0.26)\end{array}$ & $\begin{array}{l}0.14 \\
(0.48)\end{array}$ & $\begin{array}{l}0.14 \\
(0.48)\end{array}$ \\
\hline Lagged CBOE Volatility Index & $\begin{array}{l}-0.35 \\
(0.29)\end{array}$ & $\begin{array}{l}0.24 \\
(0.55)\end{array}$ & $\begin{array}{l}-0.44 \\
(0.30)\end{array}$ & $\begin{array}{l}0.22 \\
(0.64)\end{array}$ & $\begin{array}{l}-2.37 \\
(1.44)\end{array}$ & $\begin{array}{l}-2.37 \\
(1.44)\end{array}$ \\
\hline Constant & $\begin{array}{l}-6.14^{* *} \\
(2.96)\end{array}$ & $\begin{array}{l}-4.46 \\
(3.73)\end{array}$ & $\begin{array}{l}-7.18^{*} \\
(3.76)\end{array}$ & $\begin{array}{l}-1.34 \\
(5.78)\end{array}$ & $\begin{array}{l}5.72 \\
(11.04)\end{array}$ & $\begin{array}{l}5.72 \\
(11.04)\end{array}$ \\
\hline Observations & 106 & 106 & 106 & 106 & 56 & 56 \\
\hline R-squared & 0.758 & 0.893 & 0.841 & 0.913 & 0.870 & 0.870 \\
\hline Test for all listing dummies $=0$ & 2.962 & 0.255 & 20.14 & 2.607 & 8.383 & 8.383 \\
\hline $\mathrm{p}$-value & 0.058 & 0.776 & 0.000 & 0.086 & 0.002 & 0.002 \\
\hline Country fixed effects & No & No & Yes & Yes & Yes & Yes \\
\hline Year fixed effects & No & Yes & No & Yes & No & No \\
\hline Comments & $\begin{array}{l}\text { includes } \\
\text { dummies for } \\
\text { rating, } \\
\text { governing law } \\
\text { \& currency }\end{array}$ & $\begin{array}{l}\text { includes } \\
\text { dummies for } \\
\text { rating, } \\
\text { governing law } \\
\text { \& currency }\end{array}$ & $\begin{array}{l}\text { includes } \\
\text { dummies for } \\
\text { rating, } \\
\text { governing law } \\
\text { \& currency }\end{array}$ & $\begin{array}{l}\text { includes } \\
\text { dummies for } \\
\text { rating, } \\
\text { governing law } \\
\text { \& currency }\end{array}$ & $\begin{array}{l}\text { includes } \\
\text { dummies for } \\
\text { rating, } \\
\text { governing law } \\
\text { \& currency }\end{array}$ & $\begin{array}{l}\text { includes } \\
\text { dummies for } \\
\text { rating, } \\
\text { governing law } \\
\text { \& currency }\end{array}$ \\
\hline
\end{tabular}

Robust standard errors in parentheses

$* * * \mathrm{p}<0.01, * * \mathrm{p}<0.05, * \mathrm{p}<0.1$ 
Table 9: Summary of selected exchanges' material listing requirements for sovereign debt

\begin{tabular}{|c|c|c|c|}
\hline & $\underline{\text { Key Listing Requirements (Summary) }}$ & $\underline{\text { Listing Fees }}$ & Other \\
\hline $\begin{array}{l}\text { Luxembourg } \\
\text { Stock Exchange }\end{array}$ & $\begin{array}{l}\text { - Prospectus compliant with provisions of EU Prospectus } \\
\text { Directive }{ }^{21} \text { applicable to sovereign issuers, }{ }^{22} \text { including: } \\
0 \text { risk factors } \\
0 \text { terms and conditions of the securities } \\
0 \text { summary information about the sovereign state } \\
0 \text { description of the tax and budgetary system, the } \\
\text { gross public debt, foreign trade and balance of } \\
\text { payment figures and foreign exchange reserves for } \\
\text { the previous two fiscal years (and significant changes } \\
\text { since the end of the fiscal year), and } \\
\text { o details of legal and arbitration proceedings in the } \\
\text { previous year } \\
\text { Exceptions: No prospectus required if } \\
\text { o Securities will be offered only to professionals (the } \\
\text { "unregulated" market) } \\
\text { - Sovereign is a member of the European Economic } \\
\text { Area (EEA) } \\
\text { Covenant that the debt securities are freely transferable }\end{array}$ & $\begin{array}{ll}\text { - } & \text { Visa fee: } € 2,000 \\
\text { - } & \text { Listing fee: } € 600-€ 2,000 \\
\text { - } & \text { Annual fee: } € 440-€ 800\end{array}$ & $\begin{array}{l}\text { - Requires } \\
\text { appointment of } \\
\text { listing agent to } \\
\text { facilitate } \\
\text { application process }\end{array}$ \\
\hline $\begin{array}{l}\text { London Stock } \\
\text { Exchange }\end{array}$ & - Same as for Luxembourg Stock Exchange & $\begin{array}{l}\text { - Admission fee of up to } \\
£ 4,200 \\
\text { - } \quad \text { No annual fee }\end{array}$ & \\
\hline $\begin{array}{l}\text { Irish Stock } \\
\text { Exchange }\end{array}$ & - Same as for Luxembourg Stock Exchange & $\begin{array}{ll}\text { - } & \text { Document Fees: } € 4,500 \\
\text { - } & \text { Formal Notice Fee: } € 440 \\
\text { - } & \text { Annual Fee: } € 2,000 \\
\end{array}$ & $\begin{array}{l}\text { - Guaranteed three- } \\
\text { day first review } \\
\text { - } \quad \text { Requires }\end{array}$ \\
\hline
\end{tabular}

\footnotetext{
${ }^{21}$ Note that such a Prospectus is required under EU law for all public offerings of securities in the EU, regardless of whether and where the securities are listed.
}

${ }^{22}$ Annex XVI of EC Regulation 809/2004. 


\begin{tabular}{|c|c|c|c|}
\hline & $\underline{\text { Key Listing Requirements (Summary) }}$ & Listing Fees & Other \\
\hline & & & $\begin{array}{l}\text { appointment of } \\
\text { listing agent to } \\
\text { facilitate approval } \\
\text { process }\end{array}$ \\
\hline $\begin{array}{l}\text { Singapore } \\
\text { Exchange }\end{array}$ & $\begin{array}{l}\text { - Appointment of local paying agent (but may be waived by } \\
\text { the exchange) } \\
\text { - Prospectus containing the principal terms and conditions the } \\
\text { of issue } \\
\text { - Exception: If the debt securities are offered without a } \\
\text { prospectus and primarily to specified investors, the offering } \\
\text { memorandum or introductory document need only contain } \\
\text { "the information that such investors would customarily } \\
\text { expect to see in such documents." } \\
\text { - Ongoing disclosure to the Exchange of any information } \\
\text { which may have a material effect on the price or value of its } \\
\text { debt securities or on an investor's decision whether to trade } \\
\text { in such debt securities }\end{array}$ & $\begin{array}{ll}\text { - } & \text { Processing } \\
& \text { S } \$ 10,000 \\
\text { - } & \text { Listing Fee: } S \$ 15,000 \\
\text { - } & \text { No annual fee }\end{array}$ & 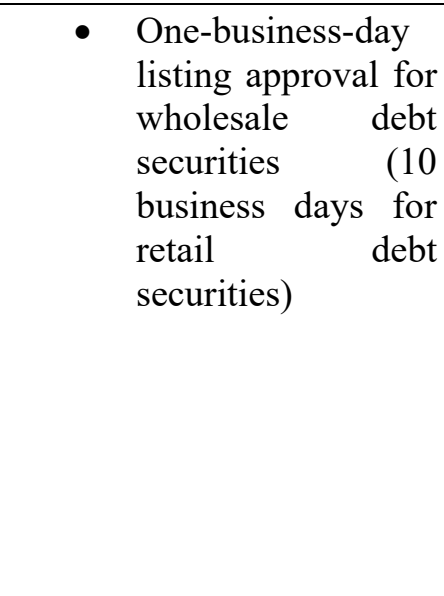 \\
\hline $\begin{array}{l}\text { Hong Kong } \\
\text { Exchanges } \\
\text { (HKEX) }\end{array}$ & $\begin{array}{l}\text { - Debt securities must be freely transferable with a } \\
\text { denomination of at least HK } \$ 500,000 \text { (or equivalent in other } \\
\text { currencies). } \\
\text { - Prospectus ("listing document") to include: } \\
\text { o Terms and conditions of the debt securities } \\
\text { o Details of the organization and administration of the } \\
\text { State } \\
\text { o Description of economic situation of the State } \\
\text { o Summary finances (income, expenditures, budget } \\
\text { forecast, and public debt) for the past } 2 \text { years } \\
\text { - Exception: If securities are offered only to professionals, } \\
\text { prospectus need only contain "the information that the } \\
\text { investors an issuer is offering the securities to would } \\
\text { customarily expect it to contain.") }\end{array}$ & $\begin{array}{l}\text { - Listing fee ranging from } \\
\text { HK } \$ 10,000 \text { to } \\
\text { HK } \$ 90,000 \text { depending } \\
\text { on maturity and size of } \\
\text { issuance }\end{array}$ & \\
\hline
\end{tabular}




\section{Table 10: Examples of investment restrictions and tax provisions tied to listed securities}

\section{$\underline{\text { Jurisdiction }}$}

Australia $^{\mathrm{a}}$

Estonia*

Hong Kong ${ }^{\mathrm{b}}$

Poland*

Qatar $^{\mathrm{c}}$

Slovenia*

United Kingdom $^{\mathrm{d}}$

\section{Law/Investment Restriction}

Eurobonds listed on "approved stock exchanges" are automatically exempt from withholding taxes.

Pension funds are subject to $10 \%$ cap on unlisted bonds.

Mandatory provident fund schemes are permitted to invest in securities listed on "recognized stock exchanges."

Insurance companies are subject to $40 \%$ cap on unlisted securities and units in investment funds.

Banks are subject to a variable cap on investments in unlisted securities abroad.

Pension funds are subject to $10 \%$ cap on unlisted stocks and bonds.

Pension funds and individual retirement accounts are permitted to hold securities listed on "recognized stock exchanges." Eurobonds listed on such exchanges are explicitly exempt from withholding tax.

* OECD, Annual Survey of Investment Regulation of Pension Funds, 2014; OECD, Regulation of Insurance Company and Pension Fund Investment, OECD Report to G20 Finance Ministers and Central Bank Governors, September 2015.

${ }^{a}$ Income Tax Assessment Act 1936.

b Mandatory Provident Fund Schemes Authority, 2016, Section 2 of the Mandatory Provident Fund Schemes (General) Regulation.

c http://www.reuters.com/article/qatar-banks-investment-idUSL5N0ES06120130616, https://www.ft.com/content/3660e5d2-d8c1-11e2-a6cf-00144feab7de (last visited October 31, 2016).

d Income Tax Act 2007, supplemented by the Qualifying Private Placement Regulations 2015 (SI 2015/2002) 


\section{Table 11: Overview of sources}

$\underline{\text { Variables }}$

$\mathrm{S} \& \mathrm{P}$ ratings

Currency, governing law, maturity, amount issued, coupon rate, issue price

\section{Sources}

Standard and Poor's Ratings Direct

Dealogic DCM Analytics database, hand-coded bond

prospectuses and offering circulars from Thomson One Banker and Perfect Information database, Deutsche Bundesbank (statistische Beihefte zum Monatsbericht, 1968-1981), Schweizerische Nationalbank (Monatsbericht, 1945-1983), Tokyo Shoken Torihikijo (Annual statistics reports 1973-1983)

CBOE Volatility Index Bloomberg and CBOE

US Treasury yields (daily, Gurkaynak et al. (2016) interpolated)

Exchange rates LCU/USD World Development Indicators, OECD 